\title{
Emerging role of cysteinyl leukotrienes in cancer
}

\author{
Lou Saier ${ }^{1}$ and Olivier Peyruchaud ${ }^{2}$ \\ ${ }^{1}$ INSERM U1033 \\ ${ }^{2}$ INSERM
}

September 11, 2020

\begin{abstract}
Cysteinyl leukotrienes (CysLTs) are inflammatory lipid mediators that play a central role in the pathophysiology of several inflammatory diseases. Recently, there has been an increased interest in determining how these lipid mediators orchestrate tumor development and metastasis through promoting a pro-tumoral microenvironment. Upregulation of CysLTs receptors and CysLTs production is found in a number of cancers and has been associated with increased tumorigenesis. Understanding the molecular mechanisms underlying the role of CysLTs and their receptors in cancer progression will help investigate the potential of targeting CysLTs signaling for anti-cancer therapy. This review gives an overview of the biological effects of CysLTs and their receptors, along with current knowledge of their regulation and expression. It also provides a recent update on the molecular mechanisms that have been postulated to explain their role in tumorigenesis and on the potential of anti-CysLTs in the treatment of cancer.
\end{abstract}

\section{KEYWORDS}

Cysteinyl leukotrienes, inflammation, cancer, metastasis

\section{INTRODUCTION}

Cysteinyl leukotrienes (CysLTs) are one of the major constituents of the eicosanoid family of bioactive inflammatory lipid-mediators. They are rapidly generated at the site of inflammation in response to immunological and nonimmunological stimuli following the release of arachidonic acid through the 5-lipoxygenase (5-LOX) pathway (Figure 1A). The term CysLTs includes leukotriene $\mathrm{C}_{4}\left(\mathrm{LTC}_{4}\right)$, leukotriene $\mathrm{D}_{4}\left(\mathrm{LTD}_{4}\right)$, and leukotriene $\mathrm{E}_{4}\left(\mathrm{LTE}_{4}\right)$; they are structurally different from leukotriene $\mathrm{A}_{4}\left(\mathrm{LTA}_{4}\right)$ and leukotriene B4 $\left(\mathrm{LTB}_{4}\right)$, which are commonly known as leukotrienes (LTs). Leukotrienes exhibit diverse biological effects such as contraction of bronchial smooth muscle, stimulation of vascular permeability, and attraction and activation of leukocytes (Hammarström, 1983).

Historically, leukotrienes were identified in 1938 as active components of slow-reacting substance of anaphylaxis (SRS-A) that causes contraction of smooth muscle in lung perfusates (Haeggström \& Funk, 2011). Murphy and colleagues later identified CysLTs as lipids conjugated to glutathione (GSH). The term "leukotrienes" was introduced at that time by Samuelsson for lipids generated by "leuko"cytes that contain three conjugated double bonds, i.e. "tri-enes".

The CysLTs are mainly biosynthesized by leukocytes from the myeloblastic lineage (in particular by eosinophils, basophils, and mast cells), and monoblastic lineages (monocytes/macrophages) as well as by dendritic cells (Peters-Golden \& Henderson, 2007). CysLTs are primarly studied for their bronchoconstriction properties during allergic inflammation but are also known to increase vascular permeability and to regulate smooth muscle tone. CysLTs have a clear role in asthma and allergic rhinitis but have also been implicated in the pathogenesis of many acute and chronic inflammatory diseases including cardiovascular, gastrointestinal, immune, and neurodegenerative diseases (Haeggström \& Funk, 2011). 
Inflammation in the tumor microenvironment is now recognized as one of the hallmarks of cancer. Lipid mediators such as CysLTs play a central role in inflammation and tissue homeostasis, and are involved in cancer development. Given that both cancer cells and non-cancer stromal cells are potent producers of CysLTs, tumor progression involves an integrated response to CysLTs signaling pathways. In this review we will focus on recent insights into the role of CysLTs in tumorigenesis, from their involvement in triggering tumor epithelial cell proliferation, survival, and migration, to their involvement in adapting the tumor microenvironment (TME) by influencing angiogenesis and inflammation. Targeting CysLTs signaling could thus offer new strategies to block cancer-related inflammation.

\section{BIOLOGY OF CYSTEINYL LEUKOTRIENES}

\subsection{Intracellular cysteinyl leukotriene biosynthesis}

During an inflammatory event, arachidonic acid (AA) is released from cell membrane-derived phospholipids by phospholipase $\mathrm{A}_{2}$, particularly cytosolic $\mathrm{PLA}_{2} \alpha\left(c \mathrm{PLA}_{2} \alpha\right)$. Once mobilized into the cytosol, AA is metabolized by 5-lipoxygenase (5-LOX) in conjunction with 5-lipoxygenase-activating protein (FLAP) to generate the unstable epoxyde leukotriene $\mathrm{A}_{4}\left(\mathrm{LTA}_{4}\right)$ through the sequential lipoxygenation of AA to 5-hydroperoxyeicosatetraenoic acid (5-HpETE) and dehydratation to $\mathrm{LTA}_{4}$ (Figure 1B). $\mathrm{LTA}_{4}$ is further conjugated to reduced glutathione $(\mathrm{GSH})$ by $\mathrm{LTC}_{4}$ synthase $\left(\mathrm{LTC}_{4} \mathrm{~S}\right)$ to form $\mathrm{LTC}_{4}$. Subsequently $\mathrm{LTC}_{4}$ is exported from the cell via multidrug resistance-associated proteins 1 and $4\left(\mathrm{MRP}_{1 / 4}\right)$ (Rius, HummelEisenbeiss, \& Keppler, 2008) where a $\gamma$-glutamyl transpeptidase (GGT) cleaves the glutamic acid moiety to form $\mathrm{LTD}_{4}$, which in turn, is transformed into $\mathrm{LTE}_{4}$ by cleavage of the glycine moiety through dipeptidase enzyme (DPEP). $\mathrm{LTC}_{4}$ and $\mathrm{LTD}_{4}$ are rapidly metabolized in the blood circulation to $\mathrm{LTE}_{4}$ with a half-life between 30s and 4 min (Keppler, Huber, Baumert, \& Guhlmann, 1989). LTE 4 , the most stable among all CysLTs, accumulates in plasma and urine, and thus serves as a clinical marker (Mayatepek \& Hoffmann, 1995).

Several studies indicate that the production of CysLTs in cells is highly regulated and compartmented. Upon cell stimulation, intracellular calcium is increased and this leads to the translocation of $\mathrm{cPLA}_{2} \alpha($ Schievella, Regier, Smith, \& Lin, 1995) and 5-LOX to the nuclear envelope where FLAP and $\mathrm{LTC}_{4} \mathrm{~S}$ are embedded in the membrane ready to support the biosynthesis of CysLTs (Samuelsson, Dahlén, Lindgren, Rouzer, \& Serhan, 1987). It has been shown in osteosarcoma cells that 5-LOX translocation is a FLAP-independent process (Kargman, Vickers, \& Evans, 1992). On the other hand, FLAP enhances the activity of 5-LOX by binding to arachidonic acid (AA) and presenting it to 5-LOX. FLAP can also act as a scaffold for 5-LOX creating a multiprotein biosynthetic complex on both outer and inner membranes (Mandal et al., 2008). 5-LOX is rapidly inactivated in a $\mathrm{Ca}^{2+}$-dependent manner. It is not clear how $\mathrm{AA}$, released by $\mathrm{cPLA}_{2} \alpha$, reaches its binding site in FLAP but it is suggested that both $\mathrm{cPLA}_{2} \alpha$ and 5 -LOX are in direct contact within the nuclear membrane and that all biosynthetic components of the CysLTs pathway are spatially interconnected (Haeggström \& Funk, 2011). The compartmentalization of CysLTs biosynthesis suggests that this pathway may have additional intracellular/intranuclear functions due to the presence of cysLTs receptors inside the nuclei of colorectal adenocarcinoma and human mast cells (Y. Jiang, Borrelli, Kanaoka, Bacskai, \& Boyce, 2007a; Nielsen, Campbell, et al., 2005).

Furthermore, lipid bodies of eosinophils and neutrophils have also been identified as a source of leukotriene synthesis (Murphy, 2001). All the enzymes required for $\mathrm{LTC}_{4}$ synthesis are present within eosinophil lipid bodies and several stimuli, such as eotaxin and RANTES has been shown to elicit the formation of lipid bodies and promote $\mathrm{LTC}_{4}$ production (Bandeira-Melo, Phoofolo, \& Weller, 2001).

\section{Enzymes in cysteinyl leukotriene biosynthesis \\ 2. 5 -LOX}

As described above, 5-LOX catalyzes the first two steps in CysLTs biosynthesis in which AA is converted into the unstable epoxide $\mathrm{LTA}_{4}$ through 5-HpETE. The human 5-lipoxygenase (5-LOX) gene encodes the mature 78 - $\mathrm{kDa}$ protein consisting of 675 amino acids. 5-LOX is essentially expressed by bone marrow-derived cells of myeloid origin such as granulocytes (i.e. neutrophils, eosinophils, basophils), monocytes/macrophages, 
mast cells, as well as dendritic cells and B lymphocytes (Haeggström, 2018). The location of 5-LOX in resting cells is cell-type specific, residing in either the cytosol or the euchromatin region of the nucleus. For example, 5-LOX is cytoplasmic in peripheral blood neutrophils and eosinophils, but resides in the nucleus of alveolar macrophages and mast cells (Thomas G. Brock, 2005). The distribution and localization of 5-LOX in human neutrophils may also vary depending on the gender of the individual. While 5-LOX has been localized in the cytoplasm of resting cells and is supposed to be translocated to nucleus upon stimulation in female neutrophils, 5-LOX has been detected in both the cytosolic and nuclear compartments of resting male neutrophils (Rakesh Kumar Singh, 2020). Although detected in the cytosolic and nucleosolic fraction of resting cells, cellular activation leads to 5-LOX translocation, in a calcium-dependent manner, to the nuclear envelope where colocalization with FLAP is a prerequisite for LT synthesis (Evans, Ferguson, Mosley, \& Hutchinson, 2008). In all cell types, upon increased intracellular calcium and p38 MAPK-activated protein kinase 2 (MK2)-mediated phosphorylation and activation, 5-LOX is translocated to the nuclear membrane (Moore \& Pidgeon, 2017). These observations indicate that both cytoplasmic and nuclear 5-LOX can be activated to produce leukotrienes, although in eosinophils nuclear import of 5-LOX from cytosol is associated with a reduced capacity to synthesize $\mathrm{LTC}_{4}$ (T. G. Brock, Anderson, Fries, Peters-Golden, \& Sporn, 1999).

The expression of 5-LOX is tightly regulated (Figure 1C) and is increased during differentiation processes. Hence, human monocytes lose 5-LOX expression when kept in culture for 7 days - probably due to the lack in required growth factors (Rådmark, Werz, Steinhilber, \& Samuelsson, 2007). 5-LOX expression is increased by different cytokines and growth factors such as TGF- $\beta$ and vitamin D3 in HL-60 cells and Mono Mac 6 cells (Steinhilber, Rådmark, \& Samuelsson, 1993), IL-3 in mouse mast cells (Murakami et al., 1995), and GM-CSF in mature neutrophils (Pouliot, McDonald, Khamzina, Borgeat, \& McColl, 1994). On the other hand, IL-4 reduces 5-LOX expression in monocytes and maturing dendritic cells (Spanbroek et al., 2001). 5 -LOX activity can potentially be modulated through the action of different kinases as it has been shown - at least in vitro - that 5-LOX is phosphorylated at several sites including: Ser271 by MK2, Ser663 by ERK, Ser523 by protein kinase A (PKA), and Tyr42, Tyr53 and Tyr94 by Src kinase (Rådmark, Werz, Steinhilber, \& Samuelsson, 2015). Phosphorylation of 5-LOX by activation of MK2 and ERK enhances leukotriene formation by inducing nuclear translocation whereas phosphorylation by PKA directly inhibits leukotriene synthesis and interferes with 5-LOX nuclear translocation (Luo et al., 2004; Werz, Bürkert, et al., 2002; Werz, Szellas, Steinhilber, \& Rådmark, 2002). In addition, 5-LOX activity is inhibited by nitric oxide and glutathione peroxidase (Thomas G. Brock, 2005). Intriguingly, neutrophils and monocytes from males have a lower capacity to produce leukotrienes, as compared to these cells from females - which paradoxically is due to androgen-induced ERK activation (Haeggström \& Funk, 2011). However, such studies need further investigation to establish a possible link between gender-specific CysLTs synthesis and the occurrence of hormone-dependent cancers.

\subsubsection{FLAP}

Unlike other enzymes in the leukotriene pathway, FLAP does not present any enzymatic activity. However, studies have demonstrated that FLAP is necessary for 5-LOX activity and thus CysLTs biosynthesis by acting as a substrate carrier that presents AA to 5-LOX (Gomes, Felipe da Costa, \& Colquhoun, 2018). FLAP is a member of the membrane-associated protein involved in eicosanoid and GSH metabolism or MAPEG family along with LTC4S with whom it shares $33 \%$ sequence identity. However, FLAP lacks a GSH binding site and GSH-conjugating activity (Lam \& Austen, 2002). It has been localized to the nuclear envelope of resting and activated neutrophils and is distributed between the inner and outer nuclear membranes and peripheral ER (Christmas, Weber, McKee, Brown, \& Soberman, 2002). Similarly to 5-LOX, GM-CSF upregulates FLAP in human neutrophils, suggesting a coordinated regulation of these two proteins (Pouliot et al., 1994) (Figure 1C).In addition, FLAP is upregulated by IL-5 in human eosinophils (Cowburn, Holgate, \& Sampson, 1999) and by TNF- $\alpha$ and lipopolysaccharide (LPS) in THP-1 human monocytic cells(Reddy, Serio, Hodulik, \& Bigby, 2003).

\subsubsection{LTC4S}

LTC4S catalyzes the first committed step in the biosynthesis of CysLTs through conjugation of GSH to 
$\mathrm{LTA}_{4}$. Unlike conventional GSH-transferases, $\mathrm{LTC}_{4} \mathrm{~S}$ does not conjugate xenobiotics and is selective for

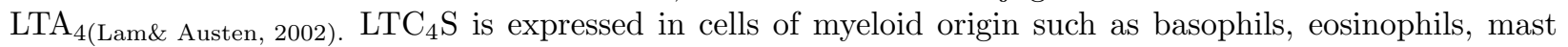
cells and monocytes/macrophages (Peters-Golden \& Henderson, 2007). LTC $_{4} \mathrm{~S}$ is also detected in several cells that lack 5-LOX - and therefore cannot produce the LTA 4 substrate - such as platelets, vascular smooth cells and endothelial cells but allows these cells to implement transcellular biosynthesis of CysLT when they interact with $\mathrm{LTA}_{4}$-producing cells (Capra et al., 2015). This topic will be further discussed in paragraph 1.3 .

Some biophysical evidence has been presented indicating that FLAP and $\mathrm{LTC}_{4} \mathrm{~S}$ form functional dimers and trimers within the membrane and that together with 5-LOX, they form an interconnected machinery necessary for CysLTs biosynthesis (Haeggström \& Funk, 2011). $\mathrm{LTC}_{4} \mathrm{~S}$ is an $18-\mathrm{kDa}$ membrane protein that is present in the outer nuclear membrane and peripheral endoplasmic reticulum but is excluded from the inner nuclear membrane. The active site of LTC4S is localized in the lumen indicating that LTC $_{4}$ must be returned to the cytoplasmic side of the membrane for its export (Christmas et al., 2002). Induction of genes encoding MAPEGs such as FLAP and $\mathrm{LTC}_{4} \mathrm{~S}$ is mediated by a series of transcription factors such as $\mathrm{C} / \mathrm{EBP} \alpha, \mathrm{C} / \mathrm{EBP} \delta$, and $\mathrm{C} / \mathrm{EBP} \varepsilon, \mathrm{NF}-\varkappa \mathrm{B}$ and Early growth response protein 1 (EGR-1) (Higgins \& Hayes, 2011). Upregulation of $\mathrm{LTC}_{4} \mathrm{~S}$ is mediated by TGF $\beta$ in THP-1 cells (Riddick et al., 1999), IL-3 and IL-5 in human eosinophils (Boyce et al., 1996) and IL-4 in human cord blood-derived mast cells (Hsieh, Lam, Penrose, Austen, \& Boyce, 2001) (Figure 1C). On the other hand, TNF- $\alpha$ downregulates $\mathrm{LTC}_{4} \mathrm{~S}$ expression in THP-1 cells via a transcriptional mechanism involving activation of p50 and p65 (Serio, Luo, Luo, \& Mao, 2007).

\subsubsection{Other enzymes with $\mathrm{LTC}_{4} \mathrm{~S}$ activity}

As mentioned above $\mathrm{LTC}_{4} \mathrm{~S}$ is a member of the MAPEG superfamily. This family further comprises FLAP, MGST1, MGST2, MGST3, and microsomal prostaglandin E synthase (mPGES) according to sequence identity, structural properties, and enzymatic activities (Jakobsson, Morgenstern, Mancini, Ford-Hutchinson, \& Persson, 1999). Among this family, MGST2 and MGST3 have been shown to catalyze conjugation of $\mathrm{LTA}_{4}$ with glutathione (Jakobsson, Mancini, \& Ford-Hutchinson, 1996; Jakobsson, Mancini, Riendeau, \& FordHutchinson, 1997). MGST2 demonstrates a $44 \%$ identity with $\mathrm{LTC}_{4} \mathrm{~S}$ and accounts for $\mathrm{LTC}_{4}$ synthesis in nonhematopoietic cells such as in the endothelium and testis (Scoggan, Jakobsson, \& Ford-Hutchinson, 1997; Sjöström, Jakobsson, Heimburger, Palmblad, \& Haeggström, 2001). MGST2 is predominantly detected in human endothelial cells and liver microsomes where it potentially is the principal enzyme responsible for LTC $_{4}$ production (Scoggan et al., 1997). MGST3 presents $27 \%$ amino acid identity with LTC4S and is widely expressed being found in human heart, skeletal muscle, and adrenal cortex, as well as in brain, placenta, liver, and kidney tissues. MGST3 is able to catalyze in vitro both the reduction of 5-HPETE to 5-HETE and the production of $\mathrm{LTC}_{4}$ from $\mathrm{LTA}_{4}$ and GSH that may occur under pathophysiological situations (Jakobsson et al., 1997).

\subsection{5. $\gamma$-Glutamyl transpeptidases (GGT1, GGT5)}

GGT1 is the principal $\gamma$-glutamyl transpeptidase that cleaves glutamic acid from $\mathrm{LTC}_{4}$ to form $\mathrm{LTD}_{4}$ at the plasma membrane. For many years, GGT1 was thought to be the only enzyme that could cleave this gammaglutamyl bond until Heisterkamp and colleagues reported in 1991 the discovery of a human enzyme, later named GGT5, with 39.5\% homology to human GGT1 that could also metabolize $\mathrm{LTC}_{4}$ to $\mathrm{LTD}_{4}$ although with less catalytic activity for LTC $_{4}$ than GGT1 (Wickham, West, Cook, \& Hanigan, 2011). GGT1 and GGT5 are both extracellular enzymes, type II membrane glycoproteins, and the only catalytic activity members of the GGT family (Wickham et al., 2011). GGT1 is up-regulated by IL-1 $\beta$ in A549 epithelial lung cancer cells (Lukic et al., 2016), and GGT5 by IFN $\gamma$ and IL-4 in human macrophages (Hanigan, Gillies, Wickham, Wakeham, \& Wirsig-Wiechmann, 2015) (Figure 1C). In many human tissues, GGT1 and GGT5 are expressed by different cell types or localized differently on polarized cells, which may result in unique roles for GGT1 and GGT5 (Hanigan et al., 2015).

2.2.6. Dipeptidases (DPEP1, DPEP2) 
DPEP1 (also known as renal dipeptidase) is a $55 \mathrm{kDa}$ membrane-bound dipeptidase which hydrolyzes a wide range of substrates, including the conversion of $\mathrm{LTD}_{4}$ to $\mathrm{LTE}_{4}$. It was long believed to be the only enzyme able to cleave glycine from $\mathrm{LTD}_{4}$ to form LTE 4 until the identification of DPEP2 (Habib, Shi, Cuevas, \& Lieberman, 2003). DPEP1 is a zinc-dependent metalloproteinase that is expressed aberrantly in several cancers although its role remains controversial. DPEP1 expression is increased in colorectal cancer (CRC) and has been identified as a marker of High-Grade Intraepithelial Neoplasia (IEN) and CRC (Eisenach et al., 2013).

\section{Transcellular CysLT biosynthesis}

CysLTs are primarily produced by stimulated leukocytes that express all the enzymes required for their synthesis (Figure 1A). However, many cells lacking expression of 5-LOX were found to contain the enzymes responsible for the biochemical conversion of the unstable $\mathrm{LTA}_{4}$ into the final bioactive CysLTs. It is now clear that the production of CysLTs within a tissue, in particular in tumor tissues and sites of inflammation, takes place in a more complex manner through the cooperation of multiple cell types in which transformation of AA occurs in one cell type and then $\mathrm{LTA}_{4}$ is passed on to a second cell to complete the transformation into CysLTs. This phenomenon defined as "transcellular biosynthesis," has been well observed in vitro when neutrophils or monocytes expressing 5-LOX are incubated with endothelial cells, platelets, or vascular smooth cells, which express LTC4S (Capra et al., 2015). This transcellular process was later demonstratedin vivo in a mouse model of peritoneal inflammation (Zarini, Gijón, Ransome, Murphy, \& Sala, 2009). LTA $\mathrm{H}_{4}$ is a highly unstable molecule that has to be shielded from hydrolytic attack by water. Albumin, liposomes and fatty acid binding protein have been shown to act as chaperones and can facilitate transcellular trafficking of $\mathrm{LTA}_{4}$ during cell to cell interactions (Dickinson Zimmer, Voelker, Bernlohr, \& Murphy, 2004; Fiore \& Serhan, 1989).

Transcellular metabolism could represent an important contributor to the production of CysLTs in pathophysiologic situations such as cancer. It has been shown that more than $50 \%$ of the $\mathrm{LTA}_{4}$ produced by bovine polymorphonuclear leukocytes (PMNL) was released into the extracellular environment instead of being metabolized by the cells that synthesized it. On the other hand, when washed platelets were added to PMNL, $\mathrm{LTC}_{4}$ was the main metabolite excreted (Sala, Testa, \& Folco, 1996). This phenomenon could be largely underestimated because it is well known that immune cells, platelets, endothelial cells, and cancer cells interact with each other under inflammatory conditions potentially involved in adapting the tumor microenvironment by influencing angiogenesis, inflammation, immunosuppression or direct tumor growth.

\section{CYSTEINYL LEUKOTRIENE RECEPTORS}

Cysteinyl leukotrienes signal through two sets of $\mathrm{G}$ protein-coupled receptors (GPCRs): $\mathrm{CysLT}_{1} \mathrm{R}$ and $\mathrm{CysLT}_{2} \mathrm{R}$ for $\mathrm{LTC}_{4}$ and $\mathrm{LTD}_{4}$, and $\mathrm{CysLT}_{3} \mathrm{R}$, also known as GPR99, for $\mathrm{LTE}_{4}$. These receptors are located on the outer plasma membrane of inflammatory cells and interact with $\mathrm{G}$ proteins in the cytoplasm, thereby eliciting increases in intracellular calcium and reduction in cAMP (Peters-Golden \& Henderson, 2007). The classification of $\mathrm{CysLT}_{1} \mathrm{R}$ and $\mathrm{CysLT}_{2} \mathrm{R}$ was initially based on the differential profiles of guinea pig trachea contractions induced by either $\mathrm{LTC}_{4}$ or $\mathrm{LTD}_{4}$ and whether the response was being sensitive or resistant to a class of CysLTRs antagonists (Labat et al., 1992). This nomenclature was later introduced based on the observation that $\mathrm{CysLT}_{1}$ receptor was sensitive to inhibition by classic antagonists, whereas the $\mathrm{CysLT}_{2}$ receptor was not. Later, the cloning of these receptors in 1999 and 2000 largely confirmed these pharmacological characteristics of the $\mathrm{CysLT}_{1}$ and $\mathrm{CysLT}_{2}$ receptors (Heise et al., 2000; Lynch et al., 1999).

These receptors show differential affinity toward CysLTs (Table 1). While $\mathrm{CysLT}_{1}$ receptor has a specific affinity to CysLTs in the following order : $\mathrm{LTD}_{4}>\mathrm{LTC}_{4}>>\mathrm{LTE}_{4}$ (Lynch et al., 1999), CysLT 2 receptor responds equally to $\mathrm{LTC}_{4}$ and $\mathrm{LTD}_{4}$ with a low affinity : $\mathrm{LTD}_{4}=\mathrm{LTC}_{4}>>\mathrm{LTE}_{4}$ (Heise et al., 2000). $\mathrm{CysLT}_{3} \mathrm{R}$ only

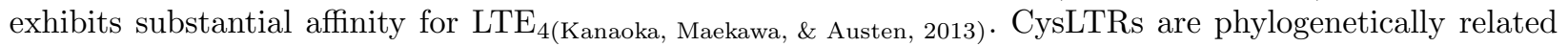
to $\mathrm{P} 2 \mathrm{Y}$ nucleotide receptors, and both $\mathrm{CysLT}_{1} \mathrm{R}$ and $\mathrm{CysLT}_{2} \mathrm{R}$ have been reported to signal in response to nucleotides in mast cells (Mellor et al., 2003) although it was later demonstrated that $\mathrm{LTD}_{4}$ and uridine diphosphate signal through separate receptors in monocytes (Capra et al., 2005). 
$\mathrm{CysLT}_{1} \mathrm{R}$

CysLT $_{1} \mathrm{R}$ encodes a 337 -amino acid protein and is expressed in many human tissues (Table 1) including lung, spleen, small intestine, placenta, and heart, as well as in several cell types such as peripheral blood leukocytes other myeloid lineage hematopoietic cells, and smooth muscle cells (Bäck et al., 2014; Lynch et al., 1999). CysLT $_{1} R$ is generally associated with the classical physiological functions elicited by CysLTs, such as bronchoconstriction, increased vascular permeability, leukocyte activation, activation of transcription factors and release of inflammatory mediators and cytokines (Bäck et al., 2014). CysLT ${ }_{1} \mathrm{R}$ is known to signal through elevation of intracellular calcium. Activation of the $\mathrm{CysLT}_{1} \mathrm{R}$ triggers signaling through either or both the Gq- and the Gi-protein depending on the cell type, most commonly through Gq (Nielsen, Campbell, et al., 2005). $\mathrm{LTD}_{4}$-initiated desensitization of $\mathrm{CysLT}_{1} \mathrm{R}$ is associated with its internalization which is dependent on a protein kinase C-dependent mechanism (Capra et al., 2005).

This receptor is targeted by antiasthmatic drugs such as Montelukast, Pranlukast, and Zafirlukast (Table 2). Some physiological functions in cells expressing both $\mathrm{CysLT}_{1} \mathrm{R}$ and $\mathrm{CysLT}_{2} \mathrm{R}$ receptors have been attributed to $\mathrm{CysLT}_{1} \mathrm{R}$ based on antagonist effects. However, most leukotriene receptor antagonists, except Montelukast and MK-571, are also active on $\mathrm{CysLT}_{2} \mathrm{R}$. In fact, $\mathrm{CysLT}_{1} \mathrm{R}$ and $\mathrm{CysLT}_{2} \mathrm{R}$ exhibit redundant activities as they both mediate cysteinyl-leukotriene-induced modulation of smooth muscle cell contraction, regulation of vascular permeability, and leukocyte activation (Bäck et al., 2014).

$\mathrm{CysLT}_{2} \mathrm{R}$

$\mathrm{CysLT}_{2} \mathrm{R}$ encodes a 345 -amino acid protein with $40 \%$ sequence identity to $\mathrm{CysLT}_{1} \mathrm{R}$. (Heise et al., 2000). $\mathrm{CysLT}_{2} \mathrm{R}$ is mainly expressed in leukocytes, including eosinophils, basophils, mast cells, and macrophages/monocytes (Bäck et al., 2011; Peters-Golden \& Henderson, 2007), but also in airway muscle cells, vascular endothelial cells, vascular smooth muscle cells, and platelets (Table 1). Studies using $\mathrm{CysLT}_{2} \mathrm{R}$-deficient mice or mice overexpressing $\mathrm{CysLT}_{2} \mathrm{R}$ in the lungs indicate that $\mathrm{CysLT}_{2} \mathrm{R}$ does not mediate bronchoconstriction, but rather contributes to inflammation, vascular permeability, and tissue fibrosis (Beller, Maekawa, Friend, Austen, \& Kanaoka, 2004; Hui et al., 2004). $\mathrm{CysLT}_{2} \mathrm{R}$ has been shown to mediate the synthesis and release of IL-33 from alveolar epithelial cells (Liu et al., 2018) and enhances platelet-mediated airway eosinophilic inflammation (Liu et al., 2019). There is currently no selective inhibitor of $\mathrm{CysLT}_{2} \mathrm{R}$ that has entered into clinical practice, but HAMI3379, BayCysLT2, and compound $15 \mathrm{~b}$ reportedly inhibit $\mathrm{CysLT}_{2} \mathrm{R}$ with high specificity (Table 2).

$\mathrm{CysLT}_{3} \mathrm{R}$

Recently, GPR99 or P2Y $\mathrm{Y}_{15}$, previously described as an oxoglutarate receptor, has been identified as $\mathrm{CysLT}_{3} \mathrm{R}$

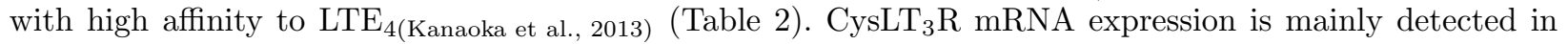
the tissue of the respiratory tract and kidneys (Inbe, Watanabe, Miyawaki, Tanabe, \& Encinas, 2004) (Table 1 ). Little is known about the pathophysiological role of $\mathrm{CysLT}_{3} \mathrm{R}$. Signaling through $\mathrm{CysLT}_{3} \mathrm{R}$ increased the number of IL-25-producing airway brush cells having modified cellular functions (Bankova et al., 2018) and caused vascular leakage during inflammatory responses (Kanaoka et al., 2013) suggesting a role in allergic and respiratory disease associated with type 2 inflammation.

Other identified CysLTs-related receptors

In addition to the $\mathrm{CysLT}_{1}, \mathrm{CysLT}_{2}$, and $\mathrm{CysLT}_{3}$ receptors, additional receptors have recently been reported to be involved in CysLTs signaling. These additional receptors include GPR17 (Ciana et al., 2006), P2Y , PPAR $\gamma$ (Sailaja Paruchuri et al., 2008), and P2Y 12 (Sailaja Paruchuri et al., 2009). GPR17 and P2Y 6 receptors have shown substantial affinity to $\mathrm{LTD}_{4}$, whereas the latter two receptors, PPAR $\gamma$, and $\mathrm{P} 2 \mathrm{Y}_{12}$ have shown a

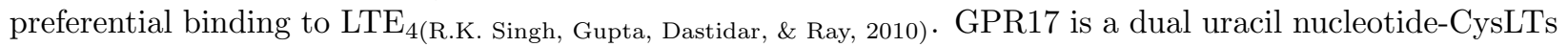
receptor highly expressed in organs that can typically undergo ischemic injury (brain, heart, and kidney) (Ciana et al., 2006). GPR17 is activated by endogenous CysLTs, including $\mathrm{LTC}_{4}$ and $\mathrm{LTD}_{4}$, and inhibited by Montelukast. GPR17 has also been shown to form a dimer with $\mathrm{CysLT}_{1} \mathrm{R}$ thus preventing $\mathrm{LTD}_{4}$-mediated activation of $\mathrm{CysLT}_{1} \mathrm{R}$ (Maekawa, Balestrieri, Austen, \& Kanaoka, 2009). However, its role as a CysLTR 
has been disputed (Benned-Jensen \& Rosenkilde, 2010). P2Y 6 , a purinergic subfamily of receptors, has been identified as a promoter of cell survival that acts as a supporting receptor for $\mathrm{CysLT}_{1} \mathrm{R}$. $\mathrm{P}_{2} \mathrm{Y}_{6}$ does not bind directly with CysLTs but mediates the activation of CysLT receptors. CysLT $_{1} \mathrm{R}$ antagonists have also been shown to inhibit the $\mathrm{P}_{2} \mathrm{Y}_{6}$ receptor (Y. Jiang, Borrelli, Bacskai, Kanaoka, \& Boyce, 2009; Lau, Chow, $\mathrm{Au}, \& \mathrm{Ko}, 2011) . \mathrm{P}_{2} \mathrm{Y}_{12}$, is a canonic type of purinergic receptor that is activated by ADP. The P2 $\mathrm{Y}_{12}$ receptor inhibition with the selective antagonist Clopidogrel is clinically used to prevent platelet aggregation and thrombosis (Cattaneo, 2015). $\mathrm{P}_{2} \mathrm{Y}_{12}$ receptor was initially identified in silico as a receptor for $\mathrm{LTE}_{4}$. It was later shown that $\mathrm{P}_{2} \mathrm{Y}_{12}$ receptor is required for $\mathrm{LTE}_{4}$-mediated pulmonary inflammation and can induce activation of Erk in transfected CHO cells, an effect of $\mathrm{LTE}_{4}$ inhibited by Clopidogrel (R. K. Singh et al., 2010). However, it is still unclear whether $\mathrm{LTE}_{4}$ binds directly to $\mathrm{P} \mathrm{Y}_{12}$ and whether its downstream signaling interacts with $\mathrm{CysLT}_{3} \mathrm{R}$-mediated activation.

\section{CYSTEINYL LEUKOTRIENES IN CANCER}

\subsection{Altered metabolism of 5-LOX pathway}

Emerging evidence indicates that lipoxygenase pathways are involved in carcinogenesis and 5-LOX is generally considered as being pro-carcinogenic. Altered metabolism of 5-LOX is found in several cancer types and has been shown to be associated with increased tumorigenesis (Wang \& Dubois, 2010). Although most attention has been focused on the cyclooxygenase pathway, a few reports indicate that 5-LOX expression is absent in normal epithelia but upregulated by pro-inflammatory stimuli and constitutively expressed in a number of cancer types including colon, oesophagus, lung, renal, pancreatic, prostate and breast cancer (Moore \& Pidgeon, 2017). 5-LOX expression has been shown to be present during the early neoplastic changes of pancreatic cancer, well before progression to invasive disease (Knab, Grippo, \& Bentrem, 2014). 5 -LOX overexpression positively correlates with high risk factors for malignant transformation to colorectal adenocarcinoma (Wasilewicz et al., 2010). These results support the role of 5-LOX in early stages of carcinogenesis. Furthermore, 5-LOX correlates with tumor stage and lymph node metastasis in colorectal adenocarcinomas (Barresi, Grosso, Vitarelli, Tuccari, \& Barresi, 2007). As mentioned before, FLAP is a protein necessary for the activity of 5-LOX. FLAP mRNA is also aberrantly expressed in breast cancers compared to normal tissues and this expression correlates with a poor prognosis (W. G. Jiang, Douglas-Jones, \& Mansel, 2006).

The mechanisms by which 5-LOX contributes to tumorigenesis have not been fully elucidated. Several studies suggest a role for 5-LOX in apoptosis. 5-LOX inhibition has been shown to induce apoptosis in pancreatic cancer cells (Tong, Ding, Witt, \& Adrian, 2002), and prostate cancer cells (Ghosh \& Myers, 1998). These inhibitors were later shown to decrease Bcl-2 protein and Mcl-1, and to increase Bax expression in human pancreatic cancer cells (Tong et al., 2002).

\subsection{Pathophysiological functions of cysteinyl leukotrienes}

CysLTs receptors have been implicated in the pathogenesis of many acute and chronic inflammatory diseases. The role of $\mathrm{CysLT}_{1} \mathrm{R}$ is not only well described in respiratory diseases such as asthma, but also in chronic vascular and immune diseases whereas $\mathrm{CysLT}_{2} \mathrm{R}$ has been particularly involved in cardiovascular diseases. However, several studies also indicate a role for CysLTRs in various cancers (Bäck et al., 2014).

Many studies suggest a relationship between patient survival and the expression of CysLTRs. Clinically, $\mathrm{CysLT}_{1} \mathrm{R}$ is overexpressed in gastric cancer, renal cell carcinoma, transitional cell carcinoma, prostate cancer, colon cancer and testicular cancer (Magnusson, Ehrnström, Olsen, \& Sjölander, 2007; Matsuyama \& Yoshimura, 2010; Venerito et al., 2011). Furthermore, strong expression of $\mathrm{CysLT}_{1} \mathrm{R}$ correlates with poor prognosis in patients with prostate, breast, and colon cancers (Bäck et al., 2014; Wang \& Dubois, 2010). Some studies identified a hotspot mutation in $\mathrm{CysLT}_{2} \mathrm{R}$ as a driver oncogene in uveal melanoma and in blue 
nevi although in other cancer types $\mathrm{CysLT}_{2} \mathrm{R}$ seems to exert anti-cancer properties (Slater et al., 2018). CysLT $_{1} \mathrm{R}$ has been shown to signal survival and proliferation in colon cancer (Table 3), suggesting an important role for this receptor in tumor development, whereas reduced expression of $\mathrm{CysLT}_{2} \mathrm{R}$ in colon cancer is associated with poor prognosis and $\mathrm{CysLT}_{2} \mathrm{R}$ signaling leads to terminal differentiation of colon carcinoma cells and growth inhibition (Magnusson et al., 2007). Interestingly, $\mathrm{LTD}_{4}$ is able to upregulate $\mathrm{CysLT}_{2} \mathrm{R}$ in both non-transformed intestinal cells and colon cancer cells but upregulates $\mathrm{CysLT}_{1} \mathrm{R}$ expression in nontransformed cells only, possibly due to the already high expression of $\mathrm{CysLT}_{1} \mathrm{R}$ in cancer cells (Yudina, Parhamifar, Bengtsson, Juhas, \& Sjölander, 2008). It has also been demonstrated that $\mathrm{CysLT}_{2} \mathrm{R}$ negatively regulates CysLT $_{1}$ R signalling in human mast cells (Y. Jiang, Borrelli, Kanaoka, Bacskai, \& Boyce, 2007b). Lack of $\mathrm{CysLT}_{2} \mathrm{R}$ may facilitate the formation of $\mathrm{CysLT}_{1} \mathrm{R}$ homodimers, leading to increased LTD4 signaling, which may promote tumorigenesis. These data thus suggest that the balance between these two receptors is important for tumor progression and disease outcome.

\subsection{Role of cysteinyl leukotrienes in carcinogenesis}

As aforementioned, pro-inflammatory CysLTs are produced by various normal and cancer cell types. These bioactive lipids can modulate tumor progression through several mechanisms (Table 3, Figure 2), such as the activation of CysLTs receptors on cancer cells, which in turn regulate cell proliferation, apoptosis and migration, or the induction of epithelial and immune cells to secrete growth factors, pro-inflammatory mediators and angiogenic factors that switch a normal microenvironment to a tumor microenvironment (TME).

\subsubsection{Proliferation and survival}

CysLTs induce cell proliferation in various cell types including bone marrow cells, smooth muscle cells, endothelial cells, and intestinal cells (Bäck et al., 2014). The activation of $\mathrm{LTD}_{4}-\mathrm{CysLT}_{1} \mathrm{R}$ signaling has been shown to promote cell proliferation and survival through multiple pathways (Table 3 ). LTD $_{4}$ induces cell proliferation in non-tumoral intestinal Int407 cells via a Ras-independent, PKC $\varepsilon$-dependent activation of ERK-1/2, and via a parallel Ras-dependent pathway (Sailaja Paruchuri, Hallberg, Juhas, Larsson, \& Sjölander, 2002). $\mathrm{LTD}_{4}$-induced activation of $\mathrm{CysLT}_{1} \mathrm{R}$ also promotes intestinal cell proliferation and survival by activation of $\beta$-catenin signaling via a PI3K-dependent phosphorylation of GSK3 $\beta$ (Maryna Mezhybovska, Wikström, Öhd, \& Sjölander, 2006). In colon cancer cells, $\mathrm{LTD}_{4}$-CysLT $\mathrm{C}_{1} \mathrm{R}$ signaling induces nuclear translocation of $\beta$-catenin and subsequent MYC and CCND1 transcription in HT116 cells, but not in HT29 cells, and reduces the GSK-3 $\beta$-induced degradation of $\beta$-catenin (Salim, Sand-Dejmek, \& Sjölander, 2014). LTD 4 not only induces $\beta$-catenin translocation to the nucleus but also to the mitochondria where it is suggested to physically interact with Bcl-2 to promote survival (Maryna Mezhybovska et al., 2006).

Hence, $\mathrm{LTD}_{4}$ promotes cell survival by increasing expression of the anti-apoptotic protein Bcl-2 in intestinal Int407 cells (Maryna Mezhybovska et al., 2006; Ohd et al., 2003), and in colon cancer Caco-2 and HT-116 cells (Bellamkonda, Sime, \& Sjölander, 2015; Wikström, Öhd, et al., 2003). LTD 4 also prevents apoptosis induced by COX-2 inhibition in intestinal cells by interfering with caspase 8 or caspase 3 activation and by activating MEK/Erk signaling (Ohd et al., 2003; Wikström, Juhas, \& Sjölander, 2003; Wikström, Öhd, et al., 2003). $\mathrm{LTD}_{4}$ - but not $\mathrm{LTC}_{4}$ - has indeed been shown to increase cell survival by up-regulating COX-2 expression and prostaglandin E2 (PGE2) production in intestinal cells (Ohd et al., 2003) and colon cancer cells (Bellamkonda et al., 2015; Ramin Massoumi, Nielsen, Azemovic, \& Sjölander, 2003), suggesting a crosstalk between CysLTs and the prostaglandins pathways. LTD 4 -induced increase of COX-2 is mediated by MAPK/Erk1-2 signaling in Int407 and Caco-2 cells (Wikström, Öhd, et al., 2003). Some results further suggest that $\mathrm{LTD}_{4}$ signals a switch from cell death to cell survival. $\mathrm{LTD}_{4}$ is known to increase MAPK protein expression in monocytic leukemia cells via a PKC $\alpha$ and Raf1 signaling pathway (Hoshino, Izumi, \& Shimizu, 1998). MAPK potentially plays a role in protecting cells against apoptosis by counteracting cell death induced by loss of matrix contact, cytoskeletal integrity or extracellular mitogenic factors and $\mathrm{LTD}_{4}$ promotes intestinal cells survival by causing a PKC-dependent upregulation of active $\beta 1$-integrins and 
enhancing $\beta 1$-integrin-dependent adhesion to collagen IV (R. Massoumi \& Sjölander, 2001).

The presence of at least two distinct intracellular signalling pathways could explain the versatile activities of CysLTs in cells under inflammatory conditions (Hoshino et al., 1998; Sailaja Paruchuri \& Sjölander, 2003). It has been shown that $\mathrm{LTD}_{4}$ can induce cell survival and proliferation by activating two parallel signaling pathways in Int407 cells: a PKC $\alpha /$ CREB pathway promoting cell survival and a PKC $/$ ERK$1 / 2 / \mathrm{p}^{\mathrm{RSK}}$ pathway promoting proliferation (Sailaja Paruchuri \& Sjölander, 2003). $\mathrm{CysLT}_{1} \mathrm{R}$ inhibition significantly reduces proliferation of both non-tumoral intestinal cell lines and colon cancer cells but inhibits survival only in non-tumoral intestinal cells. Colon cancer cells exhibit nuclear and cell surface $\mathrm{CysLT}_{1} \mathrm{R}$ and blockade of cell surface $\mathrm{CysLT}_{1} \mathrm{R}$ impairs proliferation signaling, but not cell survival. However, an apoptotic response could be induced by cell-permeable 5-LOX inhibitor that impairs endogenous production of CysLTs suggesting that nuclear $\mathrm{CysLT}_{1} \mathrm{R}$ has a role in CysLT survival signalling (Nielsen, Massoumi, Sonnerlind, \& Sjölander, 2005; S. Paruchuri, Mezhybovska, Juhas, \& Sjölander, 2006).

The proliferative effects of CysLTs also depend on the receptor subtype. While CysLT $_{1} R$ signaling induces proliferation and survival in intestinal epithelial cells and colon cancer cells, $\mathrm{CysLT}_{2} \mathrm{R}$ plays a role in terminal differentiation and growth inhibition in colon carcinoma cell lines (Magnusson et al., 2007; Mehdawi et al., 2017; Satapathy \& Sjolander, 2018). $\mathrm{CysLT}_{2} \mathrm{R}$ signaling also appears to have no effect on the level of apoptosis in MCF-7 breast cancer cells (Magnusson, Bengtsson, et al., 2011). However, $\mathrm{LTC}_{4}$ through $\mathrm{CysLT}_{2} \mathrm{R}$ signaling upregulates tumor-suppressor enzyme 15-PGDH in colon cancer cells via JNK/AP-1 and $\mathrm{TNF} \alpha$ signaling, downregulates COX-2 expression, and increases expression of the differentiation markers sucrase-isomaltase and mucin-2 (Mehdawi et al., 2017; Satapathy \& Sjolander, 2018).

\subsubsection{Migration, Invasion}

Cell migration is an essential step for tumor invasion and metastasis. LTD $_{4}$ induces non-transformed intestinal cell migration through the activation of the PI3K-Rac cascade (Sailaja Paruchuri, Broom, Dib, \& Sjölander, 2005). In epidermal carcinoma A431 cells, both $\mathrm{LTD}_{4}$ and $\mathrm{LTC}_{4}$-induced $\mathrm{CysLT}_{1} \mathrm{R}$ signaling regulated the EGF-induced second wave of Rac1 activation, a small GTPase which plays an important role in cell migration, by increasing Tiam1 expression. (Magi et al., 2014). $\mathrm{LTD}_{4}$ has been involved in the regulation of cell-matrix adhesion and migration of colon cancer cells by increasing adhesion to collagen I. LTD $_{4}$ regulates the adhesive properties and migration of Caco-2 cells by up-regulating COX-2 and stimulating PGE2 production resulting in enhanced activation and expression of $\alpha 2 \beta 1$-integrins (Ramin Massoumi et al., 2003). Epithelial-mesenchymal transition (EMT) is an essential step to cancer cell invasion and metastasis. $\mathrm{LTD}_{4}$ increases the migration of HT-116 colon cancer cells and decreases E-cadherin expression, a key mediator of the EMT process (Salim et al., 2014). $\mathrm{LTD}_{4}$ further promotes cell invasion and EMT in SW480 colon cancer cells, and increases expression of MMP-9, a metallopeptidase known to be involved in the induction of EMT in breast cancers (Vinnakota et al., 2017). Conversely $\mathrm{CysLT}_{2} \mathrm{R}$ signaling was assessed to reduce cell migration in MCF-7 breast cancer cells (Magnusson et al., 2007), and to induce cell differentiation markers and decrease MMP-2 and MMP-9 in colon cancer cells (Mehdawi et al., 2017; Satapathy \& Sjolander, 2018).

\subsubsection{Cancer-initiating cells}

The role of inflammatory lipid mediators in tumor progression is well recognized. However, whether this includes promotion of cancer-initiating cells (CICs) remains unclear. Some studies suggest that leukotrienes are involved in the regulation of stem cell homeostasis indicating their potential capacity to regulate cancer stem cell growth.

$\mathrm{LTD}_{4}$ - but not $\mathrm{LTC}_{4}$ or $\mathrm{LTE}_{4}$ - via CysLT $\mathrm{R}$ signaling supports proliferation of CD34+ hematopoeitic progenitor cells (HPCs) induced by cytokines such as IL-3, and activates the MAPK/Erk pathway leading to increase $\alpha 4 \beta 1$ and $\alpha 5 \beta 1$ integrin-dependent adhesion suggesting that CysLTs may contribute to HPCs retention and proliferation during inflammation (Boehmler et al., 2009). $\mathrm{LTD}_{4}$ and $\mathrm{PGE}_{2}$ increase the $\mathrm{ALDH}^{+}$population, a marker of cancer-initiating cells in CRC, and their resistance to radiation and 5-FU. Also, $\mathrm{LTD}_{4}$ promoted expression of self-renewal genes in $\mathrm{ALDH}^{+} \mathrm{CICs}$, the colony formation capacity, and 
tumor growth in a xenograft model of colon cancer further supporting a role for $\mathrm{LTD}_{4}$ in the promotion of cancer stemcell-like characteristics and thus tumor progression (Bellamkonda et al., 2015).

\subsubsection{Oxidative DNA damage}

$\mathrm{LTC}_{4}$ has been shown to promote oxidative DNA damage, a primary driver of carcinogenesis, contributing to genomic instabilities and increased mutations. ER-stress triggers LTC $_{4}$ synthesis by MGST2-based biosynthetic machinery and CysLTR nuclear translocation. Activation of this pathway elicits nuclear translocation of NADPH oxidase 4 (NOX4) and generation of ROS. The use of $\mathrm{LTC}_{4}$ antagonists attenuates ER stress-triggered cell death, correlating with reduced cleavage of caspase 3, whereas inhibition of the $\mathrm{LTC}_{4}$ transporter $\mathrm{MRP}_{1}$ by reversan does not reduce cleaved caspase-3 levels, thereby further demonstrating the intracrine nature of $\mathrm{LTC}_{4}$ action on cell death (Dvash, Har-Tal, Barak, Meir, \& Rubinstein, 2015).

\subsubsection{Deregulation of cell energetics}

Changes in glycolysis - also known as the Warburg effect - are implicated in the transformation and regulation of cancer cell growth, and are mediated by the "master regulator" c-Myc oncogene. $\mathrm{LTD}_{4}$ - $\mathrm{CysLT}_{1} \mathrm{R}$ signaling activates transcription of c-Myc via induction of $\beta$-catenin nuclear translocation in intestinal Int407 cells (Salim et al., 2014). LTD 4 induces the PI3K-Akt signaling pathway in Int407 cells, which has been shown to stimulate aerobic glycolysis in cancer cells (Elstrom et al., 2004). LTD 4 also triggers metabolic activity in both non-transformed Int407 cells and colon cancer Caco-2 cells by increasing NADPH activity, the ATP/ADP ratio, and the transcription of mitochondrial DNA genes (M. Mezhybovska, Yudina, Abhyankar, \& Sjölander, 2009).

\subsubsection{Tumor-promoting inflammation}

During chronic inflammation, pro-inflammatory mediators such as cytokines, chemokines and eicosanoids such as CysLTs, contribute to the shift from a normal tissue microenvironment to a TME capable of promoting tumor progression. This TME is associated with every step of tumorigenesis, from initiation, through tumor promotion, to metastatic progression. A strong association between chronic inflammation and cancer occurs in CRC that arises in patients with inflammatory bowel disease (IBD) (Wang \& Dubois, 2010). Inflammatory mediators such as CysLTs are increased at sites of inflammation and urinary $\mathrm{LTE}_{4}$ can serve as a biomarker for IBD (Stanke-Labesque, Pofelski, Moreau-Gaudry, Bessard, \& Bonaz, 2008). Several studies have shown that nonsteroidal anti-inflammatory drugs (NSAIDs) such as aspirin reduce the incidence of colon, breast, and prostate cancer (Grivennikov, Greten, \& Karin, 2010). The mechanism by which inflammatory mediators contribute to tumor cell transformation and progression has not however been completely resolved.

In response to tumor-associated or chronic inflammation, the recruitment of immune cells that are phenotypically different to normal immune cells can maintain inflammation and induce angiogenesis (Wang \& Dubois, 2010). Many studies have focused on the role of 5-LOX and leukotriene LTB4 on immune regulation but CysLTs are also potent leukocyte chemoattractants. $\mathrm{LTD}_{4}$ has been shown to induce a chemotactic response in human monocytic leukaemia THP-1 cells (Hoshino et al., 1998) and in Th17 lymphocytes, which play a role in tumorigenesis (Kim \& Lee, 2015). $\mathrm{LTD}_{4}$, via activation of transcriptional regulator EGR-1, induces production of cytokines, such as IL-8, IL-6, and TNF $\alpha$ by Hodgkin lymphoma cells which may contribute to chemotaxis of eosinophils into the tumor site and promote the synthesis of other pro-inflammatory compounds by immune cells contributing to a TME (Han et al., 2015; Schain et al., 2008). Tumor-associated macrophages (TAMs), such as M2 macrophages, play an important role in the progression of cancer. M2 macrophages secrete various cytokines including TNF $\alpha$ which is known to promote proliferation, invasion and metastasis of tumor cells, as well as $\mathrm{LTD}_{4}$ which may further promote immune cell infiltration. M2-like macrophage medium enriched in $\mathrm{TNF} \alpha$ and $\mathrm{LTD}_{4}$ promotes MMP-9 expression and induction of the EMT in colon cancer cells (Vinnakota et al., 2017). TNF- $\alpha$ and LTD4 also increase COX-2 expression in nontransformed, and 5-LOX and LTC4S in both non-transformed and cancer cell lines. TNF- $\alpha$ and $\mathrm{LTD}_{4}$, to a 
lesser extent, upregulate $\mathrm{CysLT}_{1} \mathrm{R}$ levels, These results suggest that inflammatory mediators can upregulate the eicosanoid pathway, including the CysLTs and their receptors thus providing important mechanisms for both maintaining inflammation and for tumor progression (Yudina et al., 2008).

\subsubsection{Angiogenesis}

Angiogenesis is a hallmark of cancer as tumor growth and invasion are heavily dependent on inner-tumor angiogenesis and are influenced by vascular stability. Several cells in the TME secrete various pro-angiogenic factors that stimulate endothelial cell recruitment, proliferation, migration and tubule formation. In general, endothelial cells do not have the capacity to produce leukotrienes de novodue to low or negligible enzyme expression; however they express CysLT receptors suggesting the possibility of interactions between CysLT produced by cancer cells and non-cancer cells in the microenvironment. $\mathrm{CysLT}_{1} \mathrm{R}$ and $\mathrm{CysLT}_{2} \mathrm{R}$ are both detected in vascular endothelial cells (ECs) and vascular smooth muscle cells. In particular, CysLT2 is the main CysLTR expressed by these cells and is associated with vascular permeability. LTD4-CysLT2R signaling has been shown to regulate angiogenesis in isolated murine ECs and Matrigel implants in WT mice, and to enhance ECs contraction and permeability via the Rho-dependent myosin light chain 2 and vascular endothelial (VE)-cadherin axis (Duah et al., 2019). CysLTs have been consistently shown to induce endothelial cell proliferation in vitro( $M$ a $r$ yna Mezhybovska et al., 2006; Sailaja Paruchuri \& Sjölander, 2003; Wikström, Öhd, et al., 2003). Both $\mathrm{LTC}_{4}$ and $\mathrm{LTD}_{4}$ promote angiogenesis in an in vivo chick chorioallantoic membrane system (Tsopanoglou, Pipili-Synetos, \& Maragoudakis, 1994). LTC 4 - but not LTD 4 - stimulated in vitro tube formation and migration of vascular endothelial cells and endothelial cell migration suggesting a potential synergistic action between $\mathrm{LTC}_{4}$, and $\mathrm{LTD}_{4}$ on angiogenis (Kanayasu et al., 1989). On the other hand, restoration of 15-PGDH expression through $\mathrm{LTC}_{4}$-CysLT2R signaling promotes anti-angiogenic action against colon cancer cells, decreases the VEGFR-1 protein level, and disrupts tube formation in HUVEC (Satapathy \& Sjolander, 2018). The CysLT1R antagonist Montelukast, but not the CysLT2R antagonist BayCysLT2, inhibits basal microvessel outgrowth from rat thoracic aortic rings, and both drugs inhibit an $\mathrm{LTD}_{4}$-induced model of aortic ring angiogenesis (Xu et al., 2010). CysLT 1 receptor antagonists also reduce tumor angiogenesis in a mouse xenograft model of colorectal cancer, and reduce tumor VEGF levels (Savari, Liu, Zhang, Sime, \& Sjölander, 2013). Interestingly, the recognized anti-asthmatic effect of Montelukast is modulated by VEGF polymorphisms, and Montelukast has been postulated to attenuate airway inflammation by reducing VEGF expression (Lee, Kim, Park, Jin, \& Lee, 2004).

\section{TARGETING CYSTEINYL LEUKOTRIENE SIGNALING IN CANCER MODELS}

Given the effects of CysLTs on the diverse oncogenic pathways described above, the therapeutic potential of targeting CysLT signaling for anti-cancer therapy has been investigated.

\subsection{Anti-leukotriene drugs}

The 5-LOX pathway and leukotrienes have long been linked to cancer. Several studies have aimed at targeting 5-LOX or FLAP to inhibit endogenous production of leukotrienes in in vivo cancer models. Among the 5-LOX inhibitors that have been developed, Zileuton has shown the most beneficial effects in many inflammatory diseases, and is today marketed in the United States for treatment of asthma (Haeggström, 2018). While Zileuton has had promising effects for airway disease, this drug has not yet been tested in patients with cancer. Zileuton has been investigated in animal studies and has shown promising results for multiple cancers including those of colon, lung, and pancreas (Knab et al., 2014). Zileuton reduced polyp formation in an $\mathrm{APC}^{\Delta 468}$ mouse model of polyposis and decreased tumor burden in LoVo and HT29 colon cancer murine xenocraft models (Gounaris et al., 2015; Melstrom et al., 2008). Inhibition of 5-LOX not only has a direct effect on cancer cells but has also been demonstrated to be efficient in targeting the TME. Genetic or pharmacological inhibition of 5-LOX inhibited neutrophils pro-metastatic activity and reduced subsequent lung metastasis in a mouse breast cancer model (Wculek \& Malanchi, 2015). Similar to Zileuton, MK-886, a FLAP inhibitor, has shown promising results in vitro and in vivo. MK-886 and Zileuton prevents lung tumors in mice (Gunning, Kramer, Steele, \& Pereira, 2002). MK-886 has been shown to reduce pancreatic 
cancer growth in a hamster model (Knab et al., 2014). Several studies have shown that a combination of a cyclooxygenase inhibitor and a 5-LOX or FLAP inhibitor exhibits an additive effect on reducing tumor growth in mouse model xenografts of human colon, oesophageal, breast and skin cancers (Barry et al., 2009; Chen et al., 2004; Fegn \& Wang, 2009; Rioux \& Castonguay, 1998). Few studies have evaluated the effect of specifically targeting the CysLTs pathway. Indeed, despite its central role in inflammatory diseases, very few specific inhibitors of $\mathrm{LTC}_{4} \mathrm{~S}$ have been developed so far (Kleinschmidt et al., 2015; Munck Af Rosenschöld et al., 2019). TK05 is one of the most potent $\mathrm{LTC}_{4} \mathrm{~S}$ inhibitors reported and significantly reduces vascular permeability in vivo(Kleinschmidt et al., 2015) but has not as yet been tested in cancer models.

\subsection{Cysteinyl leukotriene receptor antagonists (LTRAs)}

Cysteinyl leukotriene receptor antagonists (LTRAs) are certainly the most promising option to target CysLTs signaling as they have been on the market for more than two decades. This class of compounds, also known as "lukasts", comprises molecules such as Montelukast, Zafirlukast, and Pranlukast, that are widely prescribed drugs for the management of bronchial asthma and allergic rhinitis (Yokomizo, Nakamura, \& Shimizu, s. d.). Because of the emerging role of CysLTs in carcinogenesis and the tumor-promoting microenvironment, some studies have investigated the chemopreventive effect of LTRAs. A recent large epidemiological study on asthmatic patients showed that LTRAs decreased the risk of cancer development, especially lung, breast, colorectal, and liver cancers, in a dose-dependent manner (Tsai et al., 2016). Several in vitro studies have also demonstrated the potential of targeting $\mathrm{CysLT}_{1} \mathrm{R}$ pathways for anti-cancer therapy due to its effects on the oncogenic pathways described above. $\mathrm{CysLT}_{1} \mathrm{R}$ antagonist treatment has been shown to inhibit growth and/or induce apoptosis of a series of human cancer cell lines including urological (Matsuyama \& Yoshimura, 2010), prostate (Matsuyama et al., 2007), lung (Tsai et al., 2017), breast (Suknuntha et al., 2018), and colon cancer cells (S. Paruchuri et al., 2006; Savari et al., 2013), as well as neuroblastomas (Sveinbjörnsson et al., 2008), glioblastomas (Piromkraipak et al., 2018), and chronic myeloid leukemia (CML) (Zovko et al., 2018). However, Montelukast failed to prevent growth and colony formation of bone marrow CD34 ${ }^{+}$CD $38^{-}$leukemic stem cells from CML patients (Dolinska et al., 2017). Although LTRAs have common pharmacological properties in inhibiting $\mathrm{CysLT}_{1} \mathrm{R}$ signaling, some studies indicate that Montelukast mainly induces apoptosis, while Zafirlukast exerts its action on the cell cycle (Piromkraipak et al., 2018; Suknuntha et al., 2018). Similarly, MK-5571, a selective CysLT1R antagonist that blocks the binding of $\mathrm{LTD}_{4}$ but not $\mathrm{LTC}_{4}$, has been shown to inhibit colorectal cancer cell proliferation but not survival (S. Paruchuri et al., 2006) suggesting that CysLT could regulate apoptosis and cell proliferation through different pathways. LTRAs also suppress cell migration and invasion signaling of glioblastoma cells (Piromkraipak et al., 2018), colon cancer cells (Vinnakota et al., 2017) and skin cancer cells (Magi et al., 2014).

A few in vivo studies have reported the chemopreventive effect of CysLT1R antagonists in human colon cancer xenografts (Savari et al., 2013), in N-nitroso N-methyl urea-induced mammary carcinogenesis in rats (Jose, Amathi, Sathyamurthy, \& Kumar, 2013) in a Lewis lung carcinoma metastasis model in mice (Nozaki et al., 2010), and in vinyl carbamate-induced lung tumors in mice (Gunning et al., 2002). CysLT $_{1} \mathrm{R}$ antagonists Pranlukast and Montelukast reduce vascular permeability by regulating VEGF expression in the lungs of mice with allergen-induced asthma (Lee et al., 2004). These antagonists prevented tumor metastasis in a mouse model of Lewis lung carcinoma metastasis by inhibiting the permeability of peripheral capillaries. Interestingly, Pranlukast can inhibit tumor cell migration through both the brain and peripheral capillaries, whereas Montelukast inhibits cell migration only in peripheral capillaries (Nozaki et al., 2010). Quininib, a novel antiangiogenic and antagonist of $\mathrm{CysLT}_{1} \mathrm{R}$ and $\mathrm{CysLT}_{2} \mathrm{R}$ has also shown anti-tumor efficacy using in vitro, ex vivo and in vivo models of colorectal cancer without targeting VEGF receptors (Butler et al., 2019).

There is evidence that some of these anti-tumoral properties of LTRAs might be of a secondary nature and therefore unrelated to the $\mathrm{CysLT}_{1} \mathrm{R}$ antagonism. In particular, Montelukast, Pranlukast, and Zafirlukast inhibit PGE2 formation by inhibiting mPGES-1 activity in cytokine-stimulated HeLa and A549 carcinoma cells and in LPS-stimulated human leukocyte preparations (Kahnt et al., 2013). Although Montelukast also 
antagonizes the effect of GPR17 it is unknown if this receptor plays a role in the drug's anti-tumoral action (Ciana et al., 2006). Interest of $\mathrm{CysLT}_{2} \mathrm{R}$ agonist to exert anti-cancer properties has been suggested in the case of colorectal cancer and breast cancer (Burke et al., 2016; Magnusson, Liu, et al., 2011). Additionally, it has been revealed that both Pranlukast and BayCysLT2 could attenuate chemotherapy-triggered ROS production and DNA damage via an intracrine MGST2-LTC4 pathway, suggesting that LTC4 inhibitors may have a therapeutic potential in combination with chemotherapy to reduce the risk of secondary malignancies (Dvash et al., 2015). Moreover, CysLT2R oncogenic mutation has been identified as a potential therapeutic target in uveal melanoma (Slater et al., 2018) and $\mathrm{CysLT}_{2} \mathrm{R}$ antagonist BayCysLT2 reduces Lewis lung carcinoma tumor volume and metastasis in mice (Duah et al., 2019).

\section{CONCLUSIONS}

In conclusion, CysLTs as well as their receptors are not only important mediators of acute and chronic inflammation, but have been recognized to be essential regulators of cancer development in several cancer types. Targeting CysLT signaling has emerged as a promising pharmacological strategy considering the role of CysLTs in many hallmarks of cancer (Figure 2). Commercially available anti-asthmatic drugs which target the $\operatorname{CysLT}_{1} \mathrm{R}$, have demonstrated notable anti-tumor efficacy in in vitro and in vivo cancer models. Most CysLTs inhibitory studies largely center on targeting the tumor-promoting effects of this pathway in cancer cells. However, as evidenced in this review, CysLTs also play an important role in the cross-talk between cancer cells and stromal cells and in the orchestration of a pro-tumoral inflammatory microenvironment. A major challenge for the future will be to clarify the dual role of CysLTRs and the different CysLTs in pro- and anti-tumorigenic inflammation. Further investigation is needed to understand the role of CysLTs in the different stages of cancer and the potential for modulating CysLTs signaling in combination with other antitumor therapies in order to improve responses to treatment for a range of cancer types.

\section{BIBLIOGRAPHY}

Bäck, M., Dahlén, S.-E., Drazen, J. M., Evans, J. F., Serhan, C. N., Shimizu, T., Rovati, G. E. (2011). International Union of Basic and Clinical Pharmacology. LXXXIV : Leukotriene receptor nomenclature, distribution, and pathophysiological functions. Pharmacological Reviews , 63 (3), 539-584. https://doi.org/10.1124/pr.110.004184

Back, M., Powell, W. S., Dahlen, S.-E., Drazen, J. M., Evans, J. F., Serhan, C. N., Rovati, G. E. (2014). Update on leukotriene, lipoxin and oxoeicosanoid receptors: IUPHAR Review 7. British Journal of Pharmacology , 171 (15), 3551-3574. https://doi.org/10.1111/bph.12665

Bandeira-Melo, C., Phoofolo, M., \& Weller, P. F. (2001). Extranuclear lipid bodies, elicited by CCR3-mediated signaling pathways, are the sites of chemokine-enhanced leukotriene C4 production in eosinophils and basophils. The Journal of Biological Chemistry , 276 (25), 22779-22787. https://doi.org/10.1074/jbc.M101436200

Bankova, L. G., Dwyer, D. F., Yoshimoto, E., Ualiyeva, S., McGinty, J. W., Raff, H., Barrett, N. A. (2018). The cysteinyl leukotriene 3 receptor regulates expansion of IL-25-producing airway brush cells leading to type 2 inflammation. Science Immunology , 3 (28). https://doi.org/10.1126/sciimmunol.aat9453

Barresi, V., Grosso, M., Vitarelli, E., Tuccari, G., \& Barresi, G. (2007). 5-Lipoxygenase is coexpressed with Cox-2 in sporadic colorectal cancer : A correlation with advanced stage. Diseases of the Colon and Rectum , 50 (10), 1576-1584. https://doi.org/10.1007/s10350-007-0311-9

Barry, M., Cahill, R. A., Roche-Nagle, G., Neilan, T. G., Treumann, A., Harmey, J. H., \& Bouchier-Hayes, D. J. (2009). Neoplasms escape selective COX-2 inhibition in an animal model of breast cancer.Irish Journal of Medical Science, 178 (2), 201-208. https://doi.org/10.1007/s11845-009-0335-3

Bellamkonda, K., Sime, W., \& Sjolander, A. (2015). The impact of inflammatory lipid mediators on colon cancer-initiating cells.Molecular Carcinogenesis , 54 (11), 1315-1327. https://doi.org/10.1002/mc.22207 
Beller, T. C., Maekawa, A., Friend, D. S., Austen, K. F., \& Kanaoka, Y. (2004). Targeted gene disruption reveals the role of the cysteinyl leukotriene 2 receptor in increased vascular permeability and in bleomycin-induced pulmonary fibrosis in mice. The Journal of Biological Chemistry, 279 (44), 46129-46134. https://doi.org/10.1074/jbc.M407057200

Benned-Jensen, T., \& Rosenkilde, M. M. (2010). Distinct expression and ligand-binding profiles of two constitutively active GPR17 splice variants. British Journal of Pharmacology , 159 (5), 1092-1105. https://doi.org/10.1111/j.1476-5381.2009.00633.x

Boehmler, A. M., Drost, A., Jaggy, L., Seitz, G., Wiesner, T., Denzlinger, C., Mohle, R. (2009). The CysLT1 Ligand Leukotriene D4 Supports $\alpha 4 \beta 1$ - and $\alpha 5 \beta 1$-Mediated Adhesion and Proliferation of CD34+ Hematopoietic Progenitor Cells. The Journal of Immunology ,182 (11), 6789-6798. https://doi.org/10.4049/jimmunol.0801525

Boyce, J. A., Lam, B. K., Penrose, J. F., Friend, D. S., Parsons, S., Owen, W. F., \& Austen, K. F. (1996). Expression of LTC4 synthase during the development of eosinophils in vitro from cord blood progenitors. Blood , 88 (11), 4338-4347.

Brock, T. G., Anderson, J. A., Fries, F. P., Peters-Golden, M., \& Sporn, P. H. (1999). Decreased leukotriene C4 synthesis accompanies adherence-dependent nuclear import of 5-lipoxygenase in human blood eosinophils. Journal of Immunology (Baltimore, Md.: 1950) ,162 (3), 1669-1676.

Brock, Thomas G. (2005). Regulating leukotriene synthesis : The role of nuclear 5-lipoxygenase. Journal of Cellular Biochemistry ,96 , 1203-1211.

Burke, L., Butler, C. T., Murphy, A., Moran, B., Gallagher, W. M., O’Sullivan, J., \& Kennedy, B. N. (2016). Evaluation of Cysteinyl Leukotriene Signaling as a Therapeutic Target for Colorectal Cancer.Frontiers in Cell and Developmental Biology , 4, 103. https://doi.org/10.3389/fcell.2016.00103

Butler, C. T., Kennedy, S. A., Buckley, A., Doyle, R., Conroy, E., Gallagher, W. M., Kennedy, B. N. (2019). 1,4-dihydroxy quininib attenuates growth of colorectal cancer cells and xenografts and regulates the TIE-2 signaling pathway in patient tumours. Oncotarget , 10 (38), 3725-3744. https://doi.org/10.18632/oncotarget.26966

Capra, V., Ravasi, S., Accomazzo, M. R., Citro, S., Grimoldi, M., Abbracchio, M. P., \& Rovati, G. E. (2005). CysLT1 receptor is a target for extracellular nucleotide-induced heterologous desensitization : A possible feedback mechanism in inflammation. Journal of Cell Science, 118 (Pt 23), 5625-5636. https://doi.org/10.1242/jcs.02668

Capra, V., Rovati, G. E., Mangano, P., Buccellati, C., Murphy, R. C., \& Sala, A. (2015). Transcellular biosynthesis of eicosanoid lipid mediators. Biochimica et Biophysica Acta (BBA) - Molecular and Cell Biology of Lipids , 1851 (4), 377-382. https://doi.org/10.1016/j.bbalip.2014.09.002

Cattaneo, M. (2015). P2Y12 receptors : Structure and function. Journal of Thrombosis and Haemostasis: JTH , 13 Suppl 1 , S10-16. https://doi.org/10.1111/jth.12952

Chen, X., Wang, S., Wu, N., Sood, S., Wang, P., Jin, Z., Yang, C. S. (2004). Overexpression of 5-lipoxygenase in rat and human esophageal adenocarcinoma and inhibitory effects of zileuton and celecoxib on carcinogenesis. Clinical Cancer Research: An Official Journal of the American Association for Cancer Research , 10 (19), 6703-6709. https://doi.org/10.1158/1078-0432.CCR-04-0838

Christmas, P., Weber, B. M., McKee, M., Brown, D., \& Soberman, R. J. (2002). Membrane Localization and Topology of Leukotriene C4 Synthase.Journal of Biological Chemistry , 277 (32), 28902-28908. https://doi.org/10.1074/jbc.M203074200

Ciana, P., Fumagalli, M., Trincavelli, M. L., Verderio, C., Rosa, P., Lecca, D., Abbracchio, M. P. (2006). The orphan receptor GPR17 identified as a new dual uracil nucleotides/cysteinyl-leukotrienes receptor. The EMBO Journal , 25 (19), 4615-4627. https://doi.org/10.1038/sj.emboj.7601341 
Cowburn, A. S., Holgate, S. T., \& Sampson, A. P. (1999). IL-5 increases expression of 5-lipoxygenaseactivating protein and translocates 5-lipoxygenase to the nucleus in human blood eosinophils. Journal of Immunology (Baltimore, Md.: 1950) , 163 (1), 456-465.

Dickinson Zimmer, J. S., Voelker, D. R., Bernlohr, D. A., \& Murphy, R. C. (2004). Stabilization of leukotriene A4 by epithelial fatty acid-binding protein in the rat basophilic leukemia cell. The Journal of Biological Chemistry , 279 (9), 7420-7426. https://doi.org/10.1074/jbc.M311404200

Dolinska, M., Piccini, A., Wong, W. M., Gelali, E., Johansson, A.-S., Klang, J., Qian, H. (2017). Leukotriene signaling via ALOX5 and cysteinyl leukotriene receptor 1 is dispensable for in vitro growth of CD34+CD38stem and progenitor cells in chronic myeloid leukemia.Biochemical and Biophysical Research Communications ,490 (2), 378-384. https://doi.org/10.1016/j.bbrc.2017.06.051

Duah, E., Teegala, L. R., Kondeti, V., Adapala, R. K., Keshamouni, V. G., Kanaoka, Y., ... Paruchuri, S. (2019). Cysteinyl leukotriene 2 receptor promotes endothelial permeability, tumor angiogenesis, and metastasis. Proceedings of the National Academy of Sciences of the United States of America, 116 (1), 199-204. https://doi.org/10.1073/pnas.1817325115

Dvash, E., Har-Tal, M., Barak, S., Meir, O., \& Rubinstein, M. (2015). Leukotriene C4 is the major trigger of stress-induced oxidative DNA damage. Nature Communications , 6 , 10112. https://doi.org/10.1038/ncomms10112

Eisenach, P. A., Soeth, E., Röder, C., Klöppel, G., Tepel, J., Kalthoff, H., \& Sipos, B. (2013). Dipeptidase 1 (DPEP1) is a marker for the transition from low-grade to high-grade intraepithelial neoplasia and an adverse prognostic factor in colorectal cancer. British Journal of Cancer , 109 (3), 694-703. https://doi.org/10.1038/bjc.2013.363

Elstrom, R. L., Bauer, D. E., Buzzai, M., Karnauskas, R., Harris, M. H., Plas, D. R., Thompson, C. B. (2004). Akt stimulates aerobic glycolysis in cancer cells. Cancer Research , 64 (11), 3892-3899. https://doi.org/10.1158/0008-5472.CAN-03-2904

Evans, J. F., Ferguson, A. D., Mosley, R. T., \& Hutchinson, J. H. (2008). What's all the FLAP about? : 5-lipoxygenase-activating protein inhibitors for inflammatory diseases. Trends in Pharmacological Sciences , 29 (2), 72-78. https://doi.org/10.1016/j.tips.2007.11.006

Fegn, L., \& Wang, Z. (2009). Topical chemoprevention of skin cancer in mice, using combined inhibitors of 5-lipoxygenase and cyclo-oxygenase-2. The Journal of Laryngology and Otology, 123 (8), 880-884. https://doi.org/10.1017/S0022215109004617

Fiore, S., \& Serhan, C. N. (1989). Phospholipid bilayers enhance the stability of leukotriene A4 and epoxytetraenes : Stabilization of eicosanoids by liposomes. Biochemical and Biophysical Research Communications , 159 (2), 477-481. https://doi.org/10.1016/0006-291x(89)90017-x

Ghosh, J., \& Myers, C. E. (1998). Inhibition of arachidonate 5-lipoxygenase triggers massive apoptosis in human prostate cancer cells. Proceedings of the National Academy of Sciences of the United States of America , 95 (22), 13182-13187. https://doi.org/10.1073/pnas.95.22.13182

Gomes, R. N., Felipe da Costa, S., \& Colquhoun, A. (2018). Eicosanoids and cancer. Clinics , 73 (Suppl 1). https://doi.org/10.6061/clinics/2018/e530s

Gounaris, E., Heiferman, M. J., Heiferman, J. R., Shrivastav, M., Vitello, D., Blatner, N. R., Bentrem, D. J. (2015). Zileuton, 5-lipoxygenase inhibitor, acts as a chemopreventive agent in intestinal polyposis, by modulating polyp and systemic inflammation. PloS One , 10 (3), e0121402. https://doi.org/10.1371/journal.pone.0121402

Grivennikov, S. I., Greten, F. R., \& Karin, M. (2010). Immunity, Inflammation, and Cancer. Cell , 140 (6), 883-899. https://doi.org/10.1016/j.cell.2010.01.025 
Gunning, W. T., Kramer, P. M., Steele, V. E., \& Pereira, M. A. (2002). Chemoprevention by lipoxygenase and leukotriene pathway inhibitors of vinyl carbamate-induced lung tumors in mice. Cancer Research ,62 (15), 4199-4201.

Habib, G. M., Shi, Z.-Z., Cuevas, A. A., \& Lieberman, M. W. (2003). Identification of two additional members of the membrane-bound dipeptidase family. FASEB Journal: Official Publication of the Federation of American Societies for Experimental Biology ,17 (10), 1313-1315. https://doi.org/10.1096/fj.02-0899fje

Haeggstrom, J. Z. (2018). Leukotriene biosynthetic enzymes as therapeutic targets. Journal of Clinical Investigation ,128 (7), 2680-2690. https://doi.org/10.1172/JCI97945

Haeggstrom, J. Z., \& Funk, C. D. (2011). Lipoxygenase and Leukotriene Pathways : Biochemistry, Biology, and Roles in Disease. Chemical Reviews , 111 (10), 5866-5898. https://doi.org/10.1021/cr200246d

Hammarstrom, S. (1983). Leukotrienes. Annual Review of Biochemistry , 52 , 355-377. https://doi.org/10.1146/annurev.bi.52.070183.002035

Han, H., Xue-Franzen, Y., Miao, X., Nagy, E., Li, N., Xu, D., Claesson, H.-E. (2015). Early growth response gene (EGR)-1 regulates leukotriene D4-induced cytokine transcription in Hodgkin lymphoma cells.Prostaglandins \& Other Lipid Mediators , 121 (Pt A), 122-130. https://doi.org/10.1016/j.prostaglandins.2015.06.004

Hanigan, M. H., Gillies, E. M., Wickham, S., Wakeham, N., \& Wirsig-Wiechmann, C. R. (2015). Immunolabeling of Gamma-glutamyl transferase 5 in Normal Human Tissues Reveals Expression and Localization Differs from Gamma-glutamyl transferase 1.Histochemistry and cell biology , 143 (5), 505-515. https://doi.org/10.1007/s00418-014-1295-x

Heise, C. E., O’Dowd, B. F., Figueroa, D. J., Sawyer, N., Nguyen, T., Im, D. S., Evans, J. F. (2000). Characterization of the human cysteinyl leukotriene 2 receptor. The Journal of Biological Chemistry, 275 (39), 30531-30536. https://doi.org/10.1074/jbc.M003490200

Higgins, L. G., \& Hayes, J. D. (2011). Mechanisms of induction of cytosolic and microsomal glutathione transferase (GST) genes by xenobiotics and pro-inflammatory agents. Drug Metabolism Reviews ,43 (2), 92-137. https://doi.org/10.3109/03602532.2011.567391

Hoshino, M., Izumi, T., \& Shimizu, T. (1998). Leukotriene D4 activates mitogen-activated protein kinase through a protein kinase Calpha-Raf-1-dependent pathway in human monocytic leukemia THP-1 cells. The Journal of Biological Chemistry , 273 (9), 4878-4882. https://doi.org/10.1074/jbc.273.9.4878

Hsieh, F. H., Lam, B. K., Penrose, J. F., Austen, K. F., \& Boyce, J. A. (2001). T helper cell type 2 cytokines coordinately regulate immunoglobulin E-dependent cysteinyl leukotriene production by human cord blood-derived mast cells : Profound induction of leukotriene C(4) synthase expression by interleukin 4 . The Journal of Experimental Medicine, 193 (1), 123-133. https://doi.org/10.1084/jem.193.1.123

Hui, Y., Cheng, Y., Smalera, I., Jian, W., Goldhahn, L., Fitzgerald, G. A., \& Funk, C. D. (2004). Directed vascular expression of human cysteinyl leukotriene 2 receptor modulates endothelial permeability and systemic blood pressure. Circulation , 110 (21), 3360-3366. https://doi.org/10.1161/01.CIR.0000147775.50954.AA

Inbe, H., Watanabe, S., Miyawaki, M., Tanabe, E., \& Encinas, J. A. (2004). Identification and characterization of a cell-surface receptor, P2Y15, for AMP and adenosine. The Journal of Biological Chemistry, 279 (19), 19790-19799. https://doi.org/10.1074/jbc.M400360200

Jakobsson, P. J., Mancini, J. A., \& Ford-Hutchinson, A. W. (1996). Identification and characterization of a novel human microsomal glutathione S-transferase with leukotriene C4 synthase activity and significant sequence identity to 5-lipoxygenase-activating protein and leukotriene $\mathrm{C} 4$ synthase. The Journal of Biological Chemistry ,271 (36), 22203-22210. https://doi.org/10.1074/jbc.271.36.22203 
Jakobsson, P. J., Mancini, J. A., Riendeau, D., \& Ford-Hutchinson, A. W. (1997). Identification and characterization of a novel microsomal enzyme with glutathione-dependent transferase and peroxidase activities. The Journal of Biological Chemistry , 272 (36), 22934-22939. https://doi.org/10.1074/jbc.272.36.22934

Jakobsson, P. J., Morgenstern, R., Mancini, J., Ford-Hutchinson, A., \& Persson, B. (1999). Common structural features of MAPEG - a widespread superfamily of membrane associated proteins with highly divergent functions in eicosanoid and glutathione metabolism.Protein Science : A Publication of the Protein Society ,8 (3), 689-692.

Jiang, W. G., Douglas-Jones, A. G., \& Mansel, R. E. (2006). Aberrant expression of 5lipoxygenase-activating protein (5-LOXAP) has prognostic and survival significance in patients with breast cancer.Prostaglandins, Leukotrienes, and Essential Fatty Acids ,74 (2), 125-134. https://doi.org/10.1016/j.plefa.2005.10.005

Jiang, Y., Borrelli, L. A., Kanaoka, Y., Bacskai, B. J., \& Boyce, J. A. (2007a). CysLT2 receptors interact with CysLT1 receptors and down-modulate cysteinyl leukotriene dependent mitogenic responses of mast cells. Blood , 110 (9), 3263-3270. https://doi.org/10.1182/blood-2007-07-100453

Jiang, Y., Borrelli, L. A., Kanaoka, Y., Bacskai, B. J., \& Boyce, J. A. (2007b). CysLT2 receptors interact with CysLT1 receptors and down-modulate cysteinyl leukotriene dependent mitogenic responses of mast cells. Blood , 110 (9), 3263-3270. https://doi.org/10.1182/blood-2007-07-100453

Jiang, Y., Borrelli, L., Bacskai, B. J., Kanaoka, Y., \& Boyce, J. A. (2009). P2Y6 receptors require an intact cysteinyl leukotriene synthetic and signaling system to induce survival and activation of mast cells. Journal of Immunology (Baltimore, Md.: 1950) , 182 (2), 1129-1137. https://doi.org/10.4049/jimmunol.182.2.1129

Jose, M. A., Amathi, R., Sathyamurthy, D., \& Kumar, B. N. (2013). Chemopreventive effect of montelukast in n-nitroso n-methyl urea induced mammary carcinogenesis in female Sprague-Dawley rats. Indian Journal of Pharmacology , 45 (3), 286-288. https://doi.org/10.4103/0253-7613.111897

Kahnt, A. S., Rorsch, F., Diehl, O., Hofmann, B., Lehmann, C., Steinbrink, S. D., Maier, T. J. (2013). Cysteinyl leukotriene-receptor-1 antagonists interfere with PGE2 synthesis by inhibiting mPGES-1 activity. Biochemical Pharmacology , 86 (2), 286-296. https://doi.org/10.1016/j.bcp.2013.05.005

Kanaoka, Y., Maekawa, A., \& Austen, K. F. (2013). Identification of GPR99 protein as a potential third cysteinyl leukotriene receptor with a preference for leukotriene E4 ligand. The Journal of Biological Chemistry , 288 (16), 10967-10972. https://doi.org/10.1074/jbc.C113.453704

Kanayasu, T., Nakao-Hayashi, J., Asuwa, N., Morita, I., Ishii, T., Ito, H., \& Murota, S. (1989). Leukotriene C4 stimulates angiogenesis in bovine carotid artery endothelial cells in vitro. Biochemical and Biophysical Research Communications , 159 (2), 572-578. https://doi.org/10.1016/0006-291x(89)90032-6

Kargman, S., Vickers, P. J., \& Evans, J. F. (1992). A23187-induced translocation of 5-lipoxygenase in osteosarcoma cells. The Journal of Cell Biology , 119 (6), 1701-1709. https://doi.org/10.1083/jcb.119.6.1701

Keppler, D., Huber, M., Baumert, T., \& Guhlmann, A. (1989). Metabolic inactivation of leukotrienes. Advances in Enzyme Regulation ,28 , 307-319. https://doi.org/10.1016/0065-2571(89)90078-2

Kim, H. S., \& Lee, G. (2015). The cysteinyl leukotriene receptor CysLTR1 mediates Th17 cell migration (CAM4P.156). The Journal of Immunology , 194 (1 Supplement), 185.14-185.14.

Kleinschmidt, T. K., Haraldsson, M., Basavarajappa, D., Lundeberg, E., Thulasingam, M., Ekoff, M., Haeggstrom, J. Z. (2015). Tandem Benzophenone Amino Pyridines, Potent and Selective Inhibitors of Human Leukotriene C4 Synthase. The Journal of Pharmacology and Experimental Therapeutics , 355 (1), 108-116. https://doi.org/10.1124/jpet.115.227157

Knab, L. M., Grippo, P. J., \& Bentrem, D. J. (2014). Involvement of eicosanoids in the pathogenesis of pancreatic cancer : The roles of cyclooxygenase-2 and 5-lipoxygenase. World Journal of Gastroenterology : 
WJG , 20 (31), 10729-10739. https://doi.org/10.3748/wjg.v20.i31.10729

Labat, C., Ortiz, J. L., Norel, X., Gorenne, I., Verley, J., Abram, T. S., Gardiner, P. (1992). A second cysteinyl leukotriene receptor in human lung. The Journal of Pharmacology and Experimental Therapeutics , 263 (2), 800-805.

Lam, B. K., \& Austen, K. F. (2002). Leukotriene C4 synthase : A pivotal enzyme in cellular biosynthesis of the cysteinyl leukotrienes.Prostaglandins \& Other Lipid Mediators , 68-69 , 511-520. https://doi.org/10.1016/s0090-6980(02)00052-7

Lau, W. K., Chow, A. W., Au, S. C., \& Ko, W. (2011). Differential inhibitory effects of CysLT(1) receptor antagonists on $\mathrm{P} 2 \mathrm{Y}(6)$ receptor-mediated signaling and ion transport in human bronchial epithelia. PloS One , 6 (7), e22363. https://doi.org/10.1371/journal.pone.0022363

Lee, K. S., Kim, S. R., Park, H. S., Jin, G. Y., \& Lee, Y. C. (2004). Cysteinyl leukotriene receptor antagonist regulates vascular permeability by reducing vascular endothelial growth factor expression. Journal of Allergy and Clinical Immunology , 114 (5), 1093-1099. https://doi.org/10.1016/j.jaci.2004.07.039

Liu, T., Barrett, N. A., Kanaoka, Y., Buchheit, K., Laidlaw, T. M., Garofalo, D., Boyce, J. A. (2019). Cysteinyl leukotriene receptor 2 drives lung immunopathology through a platelet and high mobility box 1dependent mechanism. Mucosal Immunology, 12 (3), 679-690. https://doi.org/10.1038/s41385-019-0134-8

Liu, T., Barrett, N. A., Kanaoka, Y., Yoshimoto, E., Garofalo, D., Cirka, H., Boyce, J. A. (2018). Type 2 Cysteinyl Leukotriene Receptors Drive IL-33-Dependent Type 2 Immunopathology and Aspirin Sensitivity. The Journal of Immunology , 200 (3), 915-927. https://doi.org/10.4049/jimmunol.1700603

Lukic, A., Ji, J., Idborg, H., Samuelsson, B., Palmberg, L., Gabrielsson, S., \& Radmark, O. (2016). Pulmonary epithelial cancer cells and their exosomes metabolize myeloid cell-derived leukotriene C4 to leukotriene D4. Journal of Lipid Research , 57 (9), 1659-1669. https://doi.org/10.1194/jlr.M066910

Luo, M., Jones, S. M., Phare, S. M., Coffey, M. J., Peters-Golden, M., \& Brock, T. G. (2004). Protein kinase A inhibits leukotriene synthesis by phosphorylation of 5-lipoxygenase on serine 523. The Journal of Biological Chemistry, 279 (40), 41512-41520. https://doi.org/10.1074/jbc.M312568200

Lynch, K. R., O’Neill, G. P., Liu, Q., Im, D. S., Sawyer, N., Metters, K. M., .. Evans, J. F. (1999). Characterization of the human cysteinyl leukotriene CysLT1 receptor. Nature , 399 (6738), 789-793. https://doi.org/10.1038/21658

Maekawa, A., Balestrieri, B., Austen, K. F., \& Kanaoka, Y. (2009). GPR17 is a negative regulator of the cysteinyl leukotriene 1 receptor response to leukotriene D4. Proceedings of the National Academy of Sciences of the United States of America , 106 (28), 11685-11690. https://doi.org/10.1073/pnas.0905364106

Magi, S., Takemoto, Y., Kobayashi, H., Kasamatsu, M., Akita, T., Tanaka, A., Imoto, M. (2014). 5-Lipoxygenase and cysteinyl leukotriene receptor 1 regulate epidermal growth factor-induced cell migration through Tiam1 upregulation and Rac1 activation. Cancer Science , 105 (3), 290-296. https://doi.org/10.1111/cas.12340

Magnusson, C., Bengtsson, A. M., Liu, M., Liu, J., Ceder, Y., Ehrnstrom, R., \& Sjolander, A. (2011). Regulation of cysteinyl leukotriene receptor 2 expression-A potential anti-tumor mechanism. PloS One , 6 (12), e29060. https://doi.org/10.1371/journal.pone.0029060

Magnusson, C., Ehrnstrom, R., Olsen, J., \& Sjolander, A. (2007). An Increased Expression of Cysteinyl Leukotriene 2 Receptor in Colorectal Adenocarcinomas Correlates with High Differentiation. Cancer Research , 67 (19), 9190-9198. https://doi.org/10.1158/0008-5472.CAN-07-0771

Magnusson, C., Liu, J., Ehrnstrom, R., Manjer, J., Jirstrom, K., Andersson, T., \& Sjolander, A. (2011). Cysteinyl leukotriene receptor expression pattern affects migration of breast cancer cells and survival of breast cancer patients. International Journal of Cancer ,129 (1), 9-22. https://doi.org/10.1002/ijc.25648 
Mandal, A. K., Jones, P. B., Bair, A. M., Christmas, P., Miller, D., Yamin, T. D., Soberman, R. J. (2008). The nuclear membrane organization of leukotriene synthesis. Proceedings of the National Academy of Sciences of the United States of America , 105 (51), 20434-20439. https://doi.org/10.1073/pnas.0808211106

Massoumi, R., \& Sjolander, A. (2001). Leukotriene D(4) affects localisation of vinculin in intestinal epithelial cells via distinct tyrosine kinase and protein kinase $\mathrm{C}$ controlled events. Journal of Cell Science, $114(\mathrm{Pt}$ 10), 1925-1934.

Massoumi, Ramin, Nielsen, C. K., Azemovic, D., \& Sjolander, A. (2003). Leukotriene D4-induced adhesion of Caco-2 cells is mediated by prostaglandin E2 and upregulation of $\alpha 2 \beta 1$-integrin. Experimental Cell Research , 289 (2), 342-351. https://doi.org/10.1016/S0014-4827(03)00285-4

Matsuyama, M., Hayama, T., Funao, K., Kawahito, Y., Sano, H., Takemoto, Y., Yoshimura, R. (2007). Overexpression of cysteinyl LT1 receptor in prostate cancer and CysLT1R antagonist inhibits prostate cancer cell growth through apoptosis. Oncology Reports , 18 (1), 99-104.

Matsuyama, M., \& Yoshimura, R. (2010). Cysteinyl-leukotriene1 receptor is a potent target for the prevention and treatment of human urological cancer. Molecular Medicine Reports , 3 (2), 245-251. https://doi.org/10.3892/mmr_00000247

Mayatepek, E., \& Hoffmann, G. F. (1995). Leukotrienes : Biosynthesis, Metabolism, and Pathophysiologic Significance. Pediatric Research, 37 (1), 1-9. https://doi.org/10.1203/00006450-199501000-00001

Mehdawi, L. M., Satapathy, S. R., Gustafsson, A., Lundholm, K., Alvarado-Kristensson, M., \& Sjölander, A. (2017). A potential anti-tumor effect of leukotriene C4 through the induction of 15hydroxyprostaglandin dehydrogenase expression in colon cancer cells. Oncotarget , 8 (21), 35033-35047. https://doi.org/10.18632/oncotarget.16591

Mellor, E. A., Frank, N., Soler, D., Hodge, M. R., Lora, J. M., Austen, K. F., \& Boyce, J. A. (2003). Expression of the type 2 receptor for cysteinyl leukotrienes (CysLT2R) by human mast cells : Functional distinction from CysLT1R. Proceedings of the National Academy of Sciences of the United States of America , 100 (20), 11589-11593. https://doi.org/10.1073/pnas.2034927100

Melstrom, L. G., Bentrem, D. J., Salabat, M. R., Kennedy, T. J., Ding, X.-Z., Strouch, M., Adrian, T. A. (2008). Overexpression of 5-lipoxygenase in colon polyps and cancer and the effect of 5-LOX inhibitors in vitro and in a murine model. Clinical Cancer Research: An Official Journal of the American Association for Cancer Research , 14 (20), 6525-6530. https://doi.org/10.1158/1078-0432.CCR-07-4631

Mezhybovska, M., Yudina, Y., Abhyankar, A., \& Sjolander, A. (2009). Beta-catenin is involved in alterations in mitochondrial activity in non-transformed intestinal epithelial and colon cancer cells.British Journal of Cancer , 101 (9), 1596-1605. https://doi.org/10.1038/sj.bjc.6605342

Mezhybovska, Maryna, Wikstrom, K., Ohd, J. F., \& Sjolander, A. (2006). The Inflammatory Mediator Leukotriene D4 Induces $\beta$-Catenin Signaling and Its Association with Antiapoptotic Bcl-2 in Intestinal Epithelial Cells.Journal of Biological Chemistry , 281 (10), 6776-6784. https://doi.org/10.1074/jbc.M509999200

Moore, G. Y., \& Pidgeon, G. P. (2017). Cross-Talk between Cancer Cells and the Tumour Microenvironment : The Role of the 5-Lipoxygenase Pathway. International Journal of Molecular Sciences ,18 (2). https://doi.org/10.3390/ijms18020236

Munck Af Rosenschöld, M., Johannesson, P., Nikitidis, A., Tyrchan, C., Chang, H.-F., Rönn, R., Davis, A. M. (2019). Discovery of the Oral Leukotriene C4 Synthase Inhibitor (1S,2S)-2-(\{5-[(5-Chloro-2,4difluorophenyl)(2-fluoro-2-methylpropyl)amino]-3-methoxypyrazin-2-yl carbonyl)cyclopropanecarboxylic

Acid (AZD9898) as a New Treatment for Asthma. Journal of Medicinal Chemistry , 62 (17), 7769-7787. https://doi.org/10.1021/acs.jmedchem.9b00555 
Murakami, M., Austen, K. F., Bingham, C. O., Friend, D. S., Penrose, J. F., \& Arm, J. P. (1995). Interleukin3 Regulates Development of the 5-Lipoxygenase/Leukotriene C4 Synthase Pathway in Mouse Mast Cells.Journal of Biological Chemistry , 270 (39), 22653-22656. https://doi.org/10.1074/jbc.270.39.22653

Murphy, D. J. (2001). The biogenesis and functions of lipid bodies in animals, plants and microorganisms. Progress in Lipid Research ,40 (5), 325-438. https://doi.org/10.1016/S0163-7827(01)00013-3

Nielsen, C. K., Campbell, J. I. A., Ohd, J. F., Morgelin, M., Riesbeck, K., Landberg, G., \& Sjolander, A. (2005). A novel localization of the G-protein-coupled CysLT1 receptor in the nucleus of colorectal adenocarcinoma cells. Cancer Research , 65 (3), 732-742.

Nielsen, C. K., Massoumi, R., Sonnerlind, M., \& Sjolander, A. (2005). Leukotriene D4 activates distinct G-proteins in intestinal epithelial cells to regulate stress fibre formation and to generate intracellular Ca2+ mobilisation and ERK1/2 activation. Experimental Cell Research , 302 (1), 31-39. https://doi.org/10.1016/j.yexcr.2004.08.042

Nozaki, M., Yoshikawa, M., Ishitani, K., Kobayashi, H., Houkin, K., Imai, K., Muraki, T. (2010). Cysteinyl Leukotriene Receptor Antagonists Inhibit Tumor Metastasis by Inhibiting Capillary Permeability. The Keio Journal of Medicine, 59 (1), 10-18.

Ohd, J. F., Nielsen, C. K., Campbell, J., Landberg, G., Lofberg, H., \& Sjolander, A. (2003). Expression of the leukotriene D4 receptor CysLT1, COX-2, and other cell survival factors in colorectal adenocarcinomas.Gastroenterology , 124 (1), 57-70. https://doi.org/10.1053/gast.2003.50011

Paruchuri, S., Mezhybovska, M., Juhas, M., \& Sjolander, A. (2006). Endogenous production of leukotriene D4 mediates autocrine survival and proliferation via CysLT1 receptor signalling in intestinal epithelial cells. Oncogene , 25 (50), 6660-6665. https://doi.org/10.1038/sj.onc.1209666

Paruchuri, Sailaja, Broom, O., Dib, K., \& Sjolander, A. (2005). The Pro-inflammatory Mediator Leukotriene D4 Induces Phosphatidylinositol 3-Kinase and Rac-dependent Migration of Intestinal Epithelial Cells. Journal of Biological Chemistry, 280 (14), 13538-13544. https://doi.org/10.1074/jbc.M409811200

Paruchuri, Sailaja, Hallberg, B., Juhas, M., Larsson, C., \& Sjolander, A. (2002). Leukotriene D4 activates MAPK through a Ras-independent but PKC -dependent pathway in intestinal epithelial cells. Journal of Cell Science, 115 (9), 1883-1893.

Paruchuri, Sailaja, Jiang, Y., Feng, C., Francis, S. A., Plutzky, J., \& Boyce, J. A. (2008). Leukotriene E4 activates peroxisome proliferator-activated receptor gamma and induces prostaglandin D2 generation by human mast cells. The Journal of Biological Chemistry , 283 (24), 16477-16487. https://doi.org/10.1074/jbc.M705822200

Paruchuri, Sailaja, \& Sjölander, A. (2003). Leukotriene D4 Mediates Survival and Proliferation via Separate but Parallel Pathways in the Human Intestinal Epithelial Cell Line Int 407. Journal of Biological Chemistry , 278 (46), 45577-45585. https://doi.org/10.1074/jbc.M302881200

Paruchuri, Sailaja, Tashimo, H., Feng, C., Maekawa, A., Xing, W., Jiang, Y., Boyce, J. A. (2009). Leukotriene E4-induced pulmonary inflammation is mediated by the P2Y12 receptor. The Journal of Experimental Medicine, 206 (11), 2543-2555. https://doi.org/10.1084/jem.20091240

Peters-Golden, M., \& Henderson, W. R. (2007). Leukotrienes. The New England Journal of Medicine , 357 (18), 1841-1854. https://doi.org/10.1056/NEJMra071371

Piromkraipak, P., Parakaw, T., Phuagkhaopong, S., Srihirun, S., Chongthammakun, S., Chaithirayanon, K., \& Vivithanaporn, P. (2018). Cysteinyl leukotriene receptor antagonists induce apoptosis and inhibit proliferation of human glioblastoma cells by downregulating B-cell lymphoma 2 and inducing cell cycle arrest. Canadian Journal of Physiology and Pharmacology , 96 (8), 798-806. https://doi.org/10.1139/cjpp2017-0757 
Pouliot, M., McDonald, P. P., Khamzina, L., Borgeat, P., \& McColl, S. R. (1994). Granulocyte-macrophage colony-stimulating factor enhances 5-lipoxygenase levels in human polymorphonuclear leukocytes. Journal of Immunology (Baltimore, Md.: 1950) , 152 (2), 851-858.

Radmark, O., Werz, O., Steinhilber, D., \& Samuelsson, B. (2007). 5-Lipoxygenase : Regulation of expression and enzyme activity.Trends in Biochemical Sciences , 32 (7), 332-341. https://doi.org/10.1016/j.tibs.2007.06.002

Radmark, O., Werz, O., Steinhilber, D., \& Samuelsson, B. (2015). 5-Lipoxygenase, a key enzyme for leukotriene biosynthesis in health and disease. Biochimica et Biophysica Acta (BBA) - Molecular and Cell Biology of Lipids , 1851 (4), 331-339. https://doi.org/10.1016/j.bbalip.2014.08.012

Reddy, K. V., Serio, K. J., Hodulik, C. R., \& Bigby, T. D. (2003). 5-lipoxygenase-activating protein gene expression. Key role of CCAAT/enhancer-binding proteins (C/EBP) in constitutive and tumor necrosis factor (TNF) alpha-induced expression in THP-1 cells. The Journal of Biological Chemistry , 278 (16), 13810-13818. https://doi.org/10.1074/jbc.M211102200

Riddick, C. A., Serio, K. J., Hodulik, C. R., Ring, W. L., Regan, M. S., \& Bigby, T. D. (1999). TGF-beta increases leukotriene C4 synthase expression in the monocyte-like cell line, THP-1. Journal of Immunology (Baltimore, Md.: 1950), 162 (2), 1101-1107.

Rioux, N., \& Castonguay, A. (1998). Inhibitors of lipoxygenase : A new class of cancer chemopreventive agents. Carcinogenesis ,19 (8), 1393-1400. https://doi.org/10.1093/carcin/19.8.1393

Rius, M., Hummel-Eisenbeiss, J., \& Keppler, D. (2008). ATP-dependent transport of leukotrienes B4 and $\mathrm{C} 4$ by the multidrug resistance protein ABCC4 (MRP4). The Journal of Pharmacology and Experimental Therapeutics , 324 (1), 86-94. https://doi.org/10.1124/jpet.107.131342

Sala, A., Testa, T., \& Folco, G. (1996). Leukotriene A4, and not leukotriene B4, is the main 5-lipoxygenase metabolite released by bovine leukocytes. FEBS Letters , 388 (2), 94-98. https://doi.org/10.1016/00145793(96)00539-X

Salim, T., Sand-Dejmek, J., \& Sjolander, A. (2014). The inflammatory mediator leukotriene D4 induces subcellular $\beta$-catenin translocation and migration of colon cancer cells. Experimental Cell Research ,321 (2), 255-266. https://doi.org/10.1016/j.yexcr.2013.10.021

Samuelsson, B., Dahlén, S. E., Lindgren, J. A., Rouzer, C. A., \& Serhan, C. N. (1987). Leukotrienes and lipoxins : Structures, biosynthesis, and biological effects. Science (New York, N.Y.) ,237 (4819), 1171-1176. https://doi.org/10.1126/science.2820055

Satapathy, S., \& Sjolander, A. (2018). Anti-angiogenic action of leukotriene-C4 induced 15hydroxyprostaglandin dehydrogenase in colon cancer cells is a TNF- $\alpha$ dependent phenomenon. Annals of Oncology,29, v55. https://doi.org/10.1093/annonc/mdy151.195

Savari, S., Liu, M., Zhang, Y., Sime, W., \& Sjölander, A. (2013). CysLT(1)R antagonists inhibit tumor growth in a xenograft model of colon cancer. PloS One , 8 (9), e73466. https://doi.org/10.1371/journal.pone.0073466

Schain, F., Tryselius, Y., Sjöberg, J., Porwit, A., Backman, L., Malec, M., .. Claesson, H.-E. (2008). Evidence for a pathophysiological role of cysteinyl leukotrienes in classical Hodgkin lymphoma.International Journal of Cancer , 123 (10), 2285-2293. https://doi.org/10.1002/ijc.23781

Schievella, A. R., Regier, M. K., Smith, W. L., \& Lin, L. L. (1995). Calcium-mediated translocation of cytosolic phospholipase A2 to the nuclear envelope and endoplasmic reticulum. The Journal of Biological Chemistry, 270 (51), 30749-30754. https://doi.org/10.1074/jbc.270.51.30749

Scoggan, K. A., Jakobsson, P. J., \& Ford-Hutchinson, A. W. (1997). Production of leukotriene C4 in different human tissues is attributable to distinct membrane bound biosynthetic enzymes. The Journal of Biological Chemistry, 272 (15), 10182-10187. https://doi.org/10.1074/jbc.272.15.10182 
Serio, K. J., Luo, C., Luo, L., \& Mao, J. T. (2007). TNF-alpha downregulates the leukotriene C4 synthase gene in mononuclear phagocytes. American Journal of Physiology. Lung Cellular and Molecular Physiology , 292 (1), L215-222. https://doi.org/10.1152/ajplung.00023.2006

Singh, R. K., Gupta, S., Dastidar, S., \& Ray, A. (2010). Cysteinyl leukotrienes and their receptors : Molecular and functional characteristics. Pharmacology , 85 (6), 336-349. https://doi.org/10.1159/000312669

Singh, Rakesh Kumar. (2020). Antagonism of cysteinyl leukotrienes and their receptors as a neuroinflammatory target in Alzheimer's disease.Neurological Sciences: Official Journal of the Italian Neurological Society and of the Italian Society of Clinical Neurophysiology . https://doi.org/10.1007/s10072-020-04369-7

Sjostrom, M., Jakobsson, P.-J., Heimburger, M., Palmblad, J., \& Haeggstrom, J. Z. (2001). Human umbilical vein endothelial cells generate leukotriene $\mathrm{C} 4$ via microsomal glutathione $\mathrm{S}$-transferase type 2 and express the CysLT1 receptor. European Journal of Biochemistry , 268 (9), 2578-2586. https://doi.org/10.1046/j.14321327.2001.02142.x

Slater, K., Hoo, P. S., Buckley, A. M., Piulats, J. M., Villanueva, A., Portela, A., \& Kennedy, B. N. (2018). Evaluation of oncogenic cysteinyl leukotriene receptor 2 as a therapeutic target for uveal melanoma.Cancer and Metastasis Reviews , 37 (2), 335-345. https://doi.org/10.1007/s10555-018-9751-z

Spanbroek, R., Hildner, M., Kohler, A., Muller, A., Zintl, F., Kuhn, H., Habenicht, A. J. (2001). IL-4 determines eicosanoid formation in dendritic cells by down-regulation of 5-lipoxygenase and up-regulation of 15-lipoxygenase 1 expression. Proceedings of the National Academy of Sciences of the United States of America , 98 (9), 5152-5157. https://doi.org/10.1073/pnas.091076998

Stanke-Labesque, F., Pofelski, J., Moreau-Gaudry, A., Bessard, G., \& Bonaz, B. (2008). Urinary leukotriene E4 excretion : A biomarker of inflammatory bowel disease activity. Inflammatory Bowel Diseases ,14 (6), 769-774. https://doi.org/10.1002/ibd.20403

Steinhilber, D., Radmark, O., \& Samuelsson, B. (1993). Transforming growth factor beta upregulates 5lipoxygenase activity during myeloid cell maturation. Proceedings of the National Academy of Sciences of the United States of America , 90 (13), 5984-5988. https://doi.org/10.1073/pnas.90.13.5984

Suknuntha, K., Yubolphan, R., Krueaprasertkul, K., Srihirun, S., Sibmooh, N., \& Vivithanaporn, P. (2018). Leukotriene Receptor Antagonists Inhibit Mitogenic Activity in Triple Negative Breast Cancer Cells. Asian Pacific Journal of Cancer Prevention : APJCP ,19 (3), 833-837. https://doi.org/10.22034/APJCP.2018.19.3.833

Sveinbjornsson, B., Rasmuson, A., Baryawno, N., Wan, M., Pettersen, I., Ponthan, F., Kogner, P. (2008). Expression of enzymes and receptors of the leukotriene pathway in human neuroblastoma promotes tumor survival and provides a target for therapy. The FASEB Journal ,22 (10), 3525-3536. https://doi.org/10.1096/fj.07-103457

Tong, W.-G., Ding, X.-Z., Witt, R. C., \& Adrian, T. E. (2002). Lipoxygenase inhibitors attenuate growth of human pancreatic cancer xenografts and induce apoptosis through the mitochondrial pathway.Molecular Cancer Therapeutics , 1 (11), 929-935.

Tsai, M.-J., Chang, W.-A., Tsai, P.-H., Wu, C.-Y., Ho, Y.-W., Yen, M.-C., Hsu, Y.-L. (2017). Montelukast Induces Apoptosis-Inducing Factor-Mediated Cell Death of Lung Cancer Cells. International Journal of Molecular Sciences , 18 (7). https://doi.org/10.3390/ijms18071353

Tsai, M.-J., Wu, P.-H., Sheu, C.-C., Hsu, Y.-L., Chang, W.-A., Hung, J.-Y., Huang, M.-S. (2016). Cysteinyl Leukotriene Receptor Antagonists Decrease Cancer Risk in Asthma Patients. Scientific Reports ,6 , 23979. https://doi.org/10.1038/srep23979

Tsopanoglou, N. E., Pipili-Synetos, E., \& Maragoudakis, M. E. (1994). Leukotrienes C4 and D4 promote angiogenesis via a receptor-mediated interaction. European Journal of Pharmacology , 258 (1-2), 151-154. https://doi.org/10.1016/0014-2999(94)90068-x 
Venerito, M., Kuester, D., Harms, C., Schubert, D., Wex, T., \& Malfertheiner, P. (2011). Upregulation of leukotriene receptors in gastric cancer. Cancers , 3 (3), 3156-3168. https://doi.org/10.3390/cancers3033156

Vinnakota, K., Zhang, Y., Selvanesan, B. C., Topi, G., Salim, T., Sand-Dejmek, J., Sjolander, A. (2017). M2-like macrophages induce colon cancer cell invasion via matrix metalloproteinases. Journal of Cellular Physiology , 232 (12), 3468-3480. https://doi.org/10.1002/jcp.25808

Wang, D., \& Dubois, R. N. (2010). Eicosanoids and cancer. Nature Reviews. Cancer , 10 (3), 181-193. https://doi.org/10.1038/nrc2809

Wasilewicz, M. P., Kołodziej, B., Bojułko, T., Kaczmarczyk, M., Sulzyc-Bielicka, V., Bielicki, D., \& Ciepiela, K. (2010). Overexpression of 5-lipoxygenase in sporadic colonic adenomas and a possible new aspect of colon carcinogenesis. International Journal of Colorectal Disease , 25 (9), 1079-1085. https://doi.org/10.1007/s00384-010-0980-z

Wculek, S. K., \& Malanchi, I. (2015). Neutrophils support lung colonization of metastasis-initiating breast cancer cells.Nature , 528 (7582), 413-417. https://doi.org/10.1038/nature16140

Werz, O., Bürkert, E., Fischer, L., Szellas, D., Dishart, D., Samuelsson, B., Steinhilber, D. (2002). Extracellular signal-regulated kinases phosphorylate 5-lipoxygenase and stimulate 5-lipoxygenase product formation in leukocytes. FASEB Journal: Official Publication of the Federation of American Societies for Experimental Biology, 16 (11), 1441-1443. https://doi.org/10.1096/fj.01-0909fje

Werz, O., Szellas, D., Steinhilber, D., \& Radmark, O. (2002). Arachidonic acid promotes phosphorylation of 5-lipoxygenase at Ser-271 by MAPK-activated protein kinase 2 (MK2). The Journal of Biological Chemistry , 277 (17), 14793-14800. https://doi.org/10.1074/jbc.M111945200

Wickham, S., West, M. B., Cook, P. F., \& Hanigan, M. H. (2011). Gamma-glutamyl compounds : Substrate specificity of gamma-glutamyl transpeptidase enzymes. Analytical Biochemistry , 414 (2), 208-214. https://doi.org/10.1016/j.ab.2011.03.026

Wikstrom, K., Juhas, M., \& Sjolander, A. (2003). The anti-apoptotic effect of leukotriene D4 involves the prevention of caspase 8 activation and Bid cleavage. The Biochemical Journal, 371 (Pt 1), 115-124. https://doi.org/10.1042/BJ20021669

Wikstrom, K., Ohd, J. F., \& Sjolander, A. (2003). Regulation of leukotriene-dependent induction of cyclooxygenase-2 and Bcl-2.Biochemical and Biophysical Research Communications ,302 (2), 330-335. https://doi.org/10.1016/S0006-291X(03)00187-6

Xu, L., Zhang, L., Liu, L., Fang, S., Lu, Y., Wei, E., \& Zhang, W. (2010). Involvement of cysteinyl leukotriene receptors in angiogenesis in rat thoracic aortic rings. Die Pharmazie , 65 (10), 750-754.

Yokomizo, T., Nakamura, M., \& Shimizu, T. (s. d.). Leukotriene receptors as potential therapeutic targets. The Journal of Clinical Investigation , 128 (7), 2691-2701. https://doi.org/10.1172/JCI97946

Yudina, Y., Parhamifar, L., Bengtsson, A. M.-L., Juhas, M., \& Sjolander, A. (2008). Regulation of the eicosanoid pathway by tumour necrosis factor alpha and leukotriene D4 in intestinal epithelial cells.Prostaglandins, Leukotrienes and Essential Fatty Acids ,79 (6), 223-231. https://doi.org/10.1016/j.plefa.2008.09.024

Zarini, S., Gijon, M. A., Ransome, A. E., Murphy, R. C., \& Sala, A. (2009). Transcellular biosynthesis of cysteinyl leukotrienes in vivo during mouse peritoneal inflammation. Proceedings of the National Academy of Sciences of the United States of America , 106 (20), 8296-8301. https://doi.org/10.1073/pnas.0903851106

Zovko, A., Yektaei-Karin, E., Salamon, D., Nilsson, A., Wallvik, J., \& Stenke, L. (2018). Montelukast, a cysteinyl leukotriene receptor antagonist, inhibits the growth of chronic myeloid leukemia cells through apoptosis. Oncology Reports , 40 (2), 902-908. https://doi.org/10.3892/or.2018.6465

TABLES: 
Table 1. Tissue distribution of cysteinyl leukotrienes receptors

\begin{tabular}{|c|c|c|c|}
\hline Receptor & Tissue distribution & $\begin{array}{l}\text { Cells expressing } \\
\text { CysLT1R }\end{array}$ & Reference \\
\hline \multirow[t]{11}{*}{$\operatorname{CysLT}_{1} \mathbf{R}$} & Airway mucosa & $\begin{array}{l}\text { bronchial mucosal } \\
\text { eosinophils, } \\
\text { neutrophils, mast cells, } \\
\text { macrophages, } \\
\text { B-lymphocytes, and } \\
\text { plasma cells }\end{array}$ & (Zhu et al., 2005) \\
\hline & $\begin{array}{l}\text { Blood and bone } \\
\text { marrow }\end{array}$ & $\begin{array}{l}\text { Peripheral blood } \\
\text { leukocytes (eosinophils, } \\
\text { neutrophils, mono- } \\
\text { cytes/macrophages, B } \\
\text { lymphocytes), mast } \\
\text { cells, mononuclear } \\
\text { cells, monocyte } \\
\text {-derived dendritic cells, } \\
\text { platelets }\end{array}$ & $\begin{array}{l}\text { (Zhu et al., 2005), } \\
\text { (Lynch et al., 1999), } \\
\text { (Figueroa et al., 2003), } \\
\text { (Hasegawa et al., } \\
\text { 2010), (Dannull et al., } \\
\text { 2012) }\end{array}$ \\
\hline & Blood vessels & $\begin{array}{l}\text { coronary artery smooth } \\
\text { muscle cells, saphenous } \\
\text { veins, human umbilical } \\
\text { vein endothelial cells } \\
\text { (HUVECs) }\end{array}$ & $\begin{array}{l}\text { (Mechiche et al., 2004), } \\
\text { (Eaton et al., 2012), } \\
\text { (Lötzer et al., 2003) }\end{array}$ \\
\hline & Conjunctiva & $\begin{array}{l}\text { conjunctival goblet } \\
\text { cells }\end{array}$ & (Dartt et al., 2011) \\
\hline & Heart & $\begin{array}{l}\text { aortic valvular } \\
\text { myofibroblasts }\end{array}$ & (Nagy et al., 2011) \\
\hline & Lung & $\begin{array}{l}\text { bronchial smooth } \\
\text { muscle cells, alveolar } \\
\text { macrophages }\end{array}$ & $\begin{array}{l}\text { (Zhu et al., 2005), } \\
\text { (Lynch et al., 1999) }\end{array}$ \\
\hline & Nasal polyps & - & $\begin{array}{l}\text { (Pérez-Novo et al., } \\
2006 \text { ) }\end{array}$ \\
\hline & Pancreas & - & $\begin{array}{l}\text { (Lynch et al., 1999), } \\
\text { (Sarau et al., 1999) }\end{array}$ \\
\hline & Placenta & - & \\
\hline & $\begin{array}{l}\text { Small intestine and } \\
\text { colon }\end{array}$ & - & \\
\hline & Spleen & - & \\
\hline \multirow[t]{2}{*}{$\mathrm{CysLT}_{2} \mathrm{R} \mathrm{CysLT}_{2} \mathrm{R}$} & Adrenal gland & $\begin{array}{l}\text { medullary } \\
\text { pheochromocytes, } \\
\text { ganglion cells }\end{array}$ & (Heise et al., 2000) \\
\hline & $\begin{array}{l}\text { Blood and bone } \\
\text { marrow }\end{array}$ & $\begin{array}{l}\text { Peripheral blood } \\
\text { leukocytes (eosinophils, } \\
\text { basophils, monocytes), } \\
\text { mast cells, } \\
\text { mononuclear cells, } \\
\text { monocyte-derived } \\
\text { dendritic cells, platelets }\end{array}$ & $\begin{array}{l}\text { (Figueroa et al., 2003), } \\
\text { (Hasegawa et al., } \\
\text { 2010), (Heise et al., } \\
\text { 2000), (Gauvreau et } \\
\text { al., 2005) }\end{array}$ \\
\hline
\end{tabular}




\begin{tabular}{|c|c|c|c|}
\hline Receptor & Tissue distribution & $\begin{array}{l}\text { Cells expressing } \\
\text { CysLT1R }\end{array}$ & Reference \\
\hline & Blood vessels & $\begin{array}{l}\text { vascular, and coronary } \\
\text { artery smooth muscle } \\
\text { cells, saphenous veins, } \\
\text { human umbilical vein } \\
\text { endothelial cells } \\
\text { (HUVECs) }\end{array}$ & $\begin{array}{l}\text { (Hu et al., 2005), } \\
\text { (Sjöström et al., 2003), } \\
\text { (Mechiche et al., 2004) }\end{array}$ \\
\hline & $\begin{array}{l}\text { Brain and central } \\
\text { nervous system }\end{array}$ & $\begin{array}{l}\text { pituitary and spinal } \\
\text { cord, smooth muscle } \\
\text { cells of cerebral arteries } \\
\text { and veins }\end{array}$ & $\begin{array}{l}\text { (Heise et al., 2000), } \\
\text { (Hu et al., 2005) }\end{array}$ \\
\hline & Conjunctiva & $\begin{array}{l}\text { conjunctival goblet } \\
\text { cells }\end{array}$ & (Dartt et al., 2011) \\
\hline & Heart & $\begin{array}{l}\text { cardiac Purkinje cells, } \\
\text { myocytes, fibroblasts }\end{array}$ & $\begin{array}{l}\text { (Heise et al., 2000), } \\
\text { (Kamohara et al., } \\
2001 \text { ) }\end{array}$ \\
\hline & Lung & $\begin{array}{l}\text { airway smooth muscle } \\
\text { cells, interstitial } \\
\text { macrophages }\end{array}$ & (Heise et al., 2000) \\
\hline & Lymph node & - & (Heise et al., 2000) \\
\hline & Nasal mucosa & $\begin{array}{l}\text { epithelial and } \\
\text { glandular cells }\end{array}$ & (Corrigan et al., 2005) \\
\hline & Nasal polyps & - & $\begin{array}{l}\text { (Adamusiak et al., } \\
\text { 2012) }\end{array}$ \\
\hline & Placenta & - & (Takasaki et al., 2000) \\
\hline & Spleen & - & (Heise et al., 2000) \\
\hline \multirow[t]{6}{*}{$\mathrm{CysLT}_{3} \mathrm{R}$} & fetal brain & - & (Inbe et al., 2004) \\
\hline & kidney & - & $\begin{array}{l}\text { (Inbe et al., 2004), } \\
\text { (Wittenberger et al., } \\
2002 \text { ) }\end{array}$ \\
\hline & placenta & - & $\begin{array}{l}\text { (Wittenberger et al., } \\
2002)\end{array}$ \\
\hline & $\begin{array}{l}\text { Respiratory tract } \\
\text { (trachea and lung) }\end{array}$ & mast cells, basophils & (Inbe et al., 2004) \\
\hline & salivary glands & - & (Inbe et al., 2004) \\
\hline & $\begin{array}{l}\text { Kidney, testis and } \\
\text { smooth muscle (in } \\
\text { mice) }\end{array}$ & - & (He et al., 2004) \\
\hline
\end{tabular}

Table 2. Ligands of cysteinyl leukotriene receptors

\begin{tabular}{|c|c|c|c|c|c|c|c|c|c|}
\hline \multirow{2}{*}{\multicolumn{2}{|c|}{ Category Category Ligand }} & \multicolumn{8}{|c|}{$\operatorname{CysLT}_{1} R \operatorname{CysLT}_{1} \mathrm{R} \mathrm{CysLT}_{1} \mathrm{R} \mathrm{CysLT} \mathrm{C}_{2} \mathrm{R} \mathrm{CysLT}_{2} \mathrm{R} \mathrm{CysLT}_{2} \mathrm{R} \mathrm{CysLT}_{3} \mathrm{R} \mathrm{CysLT}_{3} \mathrm{R}$} \\
\hline & & Value & Param & eRefer & eValue & Param & eRefer & eValue & Parame \\
\hline \multirow[t]{2}{*}{ Agonists Agonists } & $\mathrm{LTC}_{4}$ & $\begin{array}{l}7.4- \\
7.7\end{array}$ & $\underset{\mathrm{a}}{\mathrm{pEC}_{50}}$ & $\begin{array}{l}\text { (Bäck } \\
\text { et al., } \\
2019 \text { ) }\end{array}$ & $\begin{array}{l}7.0- \\
8.6\end{array}$ & $\underset{\mathrm{a}}{\mathrm{pEC}_{50}}$ & $\begin{array}{l}\text { (Bäck } \\
\text { et al., } \\
2019 \text { ) }\end{array}$ & - & - \\
\hline & $\mathrm{LTD}_{4}$ & $\begin{array}{l}7.3- \\
9.4\end{array}$ & & & $\begin{array}{l}6.8- \\
8.6\end{array}$ & & & - & - \\
\hline
\end{tabular}




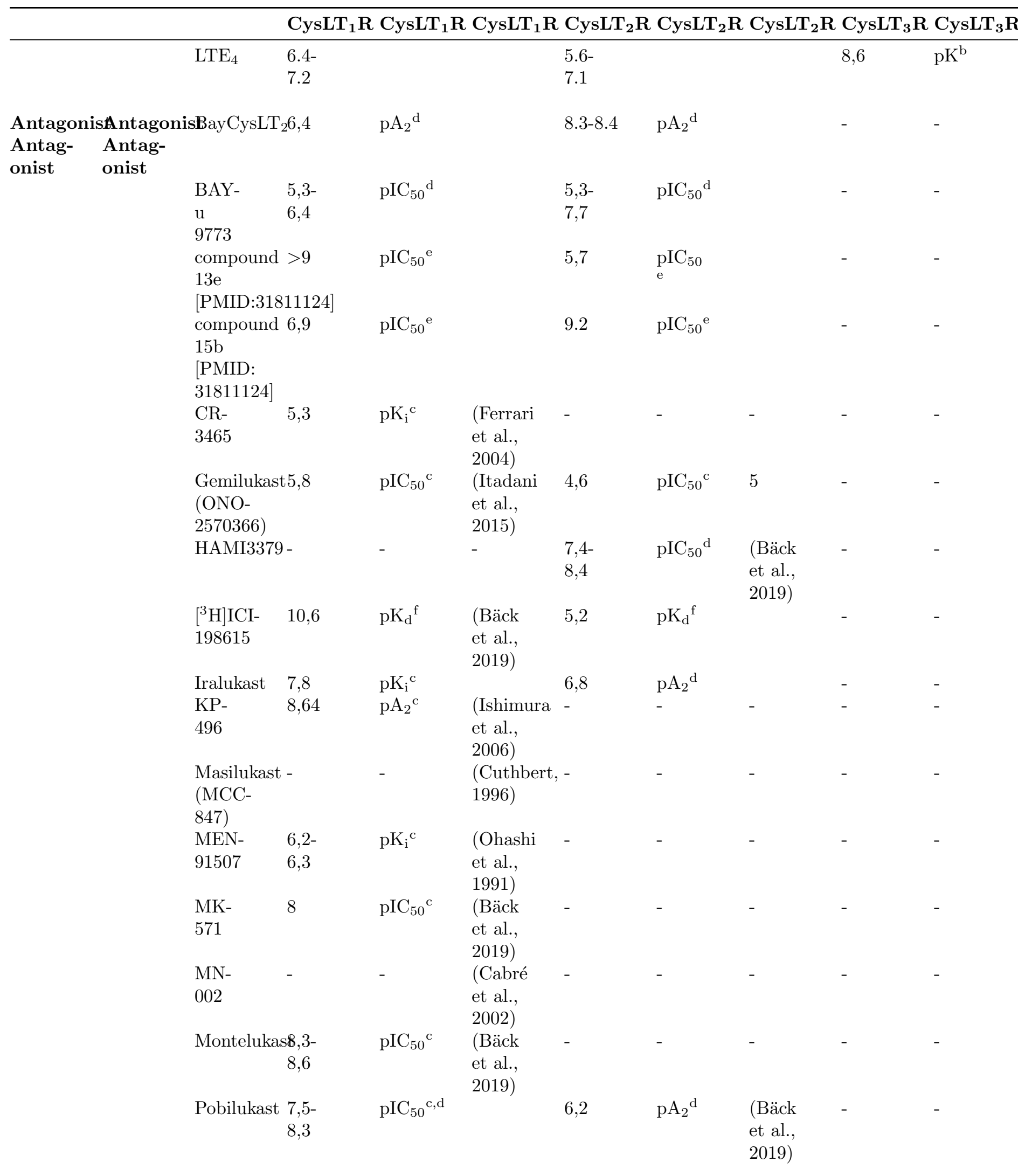




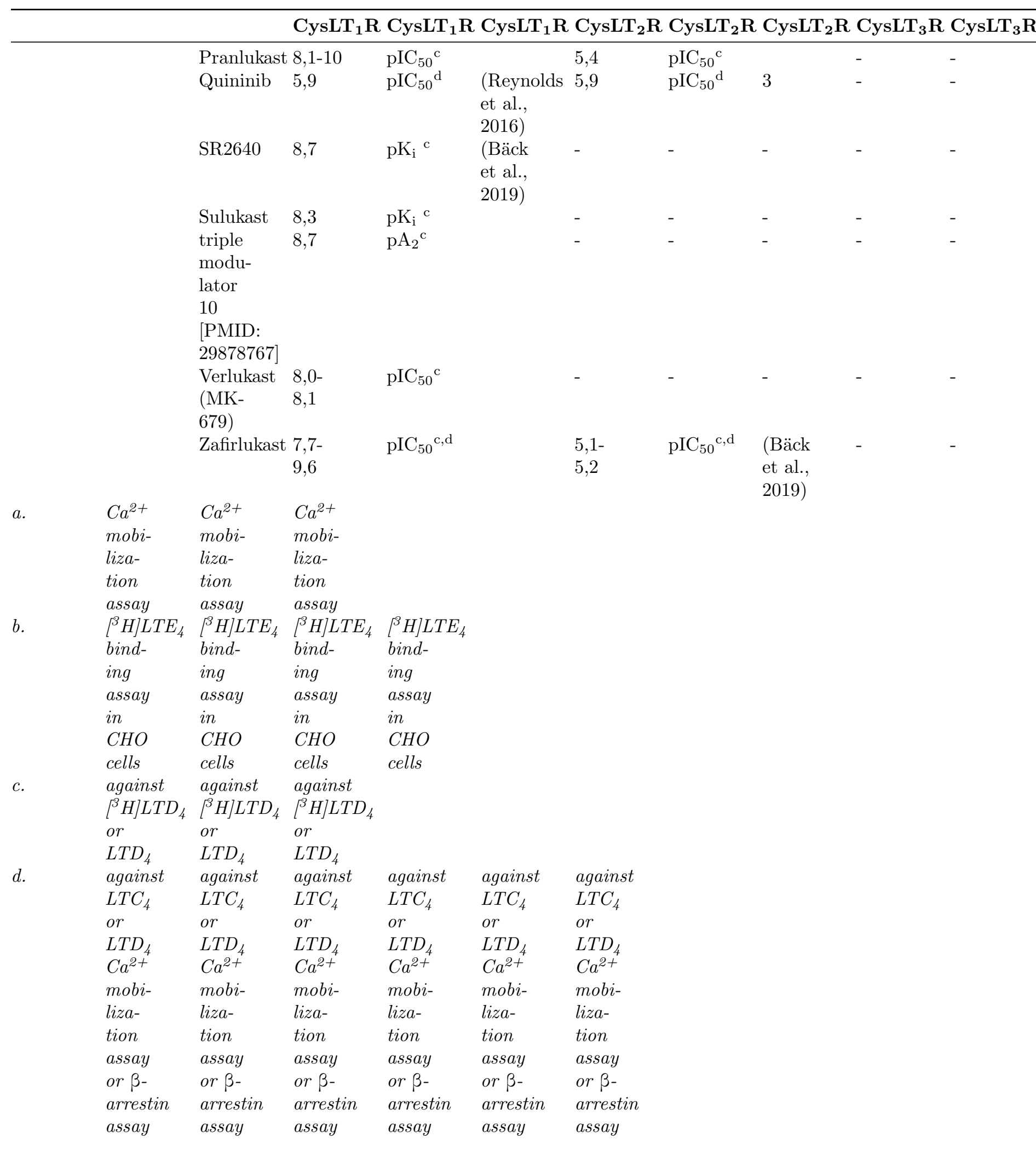




\begin{tabular}{|c|c|c|c|c|c|}
\hline & & & $\mathrm{CysLT}_{1} \mathrm{R}$ & $\mathrm{CysLT}_{1} \mathrm{R}$ & $\mathrm{CysLT}_{1} \mathrm{R} \mathrm{CysLT} \mathrm{CH}_{2} \mathrm{CysLT}{ }_{2} \mathrm{R} \mathrm{CysLT}_{2} \mathrm{R} \mathrm{CysLT}_{3} \mathrm{R} \mathrm{CysLT}_{3} \mathrm{R}$ \\
\hline \multirow[t]{10}{*}{$e}$. & against & against & against & against & against \\
\hline & LTD4- & $L T D 4^{-}$ & LTD4- & LTD4- & LTD4- \\
\hline & induced & induced & induced & induced & induced \\
\hline & $I P 1$ & IP1 & IP1 & $I P 1$ & $I P 1$ \\
\hline & pro- & pro- & pro- & pro- & pro- \\
\hline & $d u c-$ & $d u c-$ & $d u c-$ & $d u c-$ & $d u c-$ \\
\hline & tion & tion & tion & tion & tion \\
\hline & by the & by the & by the & by the & by the \\
\hline & antag- & antag- & antag- & antag- & antag- \\
\hline & onist & onist & onist & onist & onist \\
\hline \multirow[t]{8}{*}{$f}$. & antagonist & antagonist & antagonist & antagonist & antagonist \\
\hline & bind- & bind- & bind- & bind- & bind- \\
\hline & $i n g$ & $i n g$ & $i n g$ & $i n g$ & $i n g$ \\
\hline & assay & assay & assay & assay & assay \\
\hline & in $h u-$ & in hu- & in $h u-$ & in hu- & in hu- \\
\hline & $\operatorname{man}$ & $\operatorname{man}$ & man & man & man \\
\hline & lung & lung & lung & lung & lung \\
\hline & parenchyn & aparenchyn & oparenchy & oparenchymo & oparenchyma \\
\hline
\end{tabular}

Table 3. Effects of cysteinyl leukotriene receptors on cancer cells

\begin{tabular}{|c|c|c|c|c|}
\hline CysLT & Receptor & Function & Pathways & Comments \\
\hline $\mathrm{LTD}_{4}$ & $\mathrm{CysLT}_{1} \mathrm{R}$ & chemotaxis & PKC $\alpha /$ Raf-1 + PTX-sensitive G-protein & - increases MAPkinase protein expression \\
\hline $\mathrm{LTD}_{4}$ & - & survival & COX $2, \beta$-catenin, and Bcl-2 & - increases expression of COX-2, $\beta$-catenir \\
\hline $\mathrm{LTD}_{4}$ & - & survival & $\mathrm{PKC}$ & - induced relocalisation of vinculin accom \\
\hline $\mathrm{LTD}_{4}$ & - & proliferation & 1. PKC $\varepsilon$-Raf-1-MEK1/2-ERK1/2 2. Ras & - activates ERK-1/2 via a PKC $\varepsilon / \operatorname{Raf}-1 / \mathrm{M}$ \\
\hline
\end{tabular}

\begin{tabular}{|c|c|c|c|c|c|c|c|}
\hline & - & $\begin{array}{l}\text { proliferation } \\
\text { survival }\end{array}$ & $\begin{array}{l}\text { MAPK/Erk- } \\
1 / 2 \\
\text { COX2 }\end{array}$ & $\begin{array}{l}\text { - increases } \\
\text { COX-2 } \\
\text { expression } \\
\text { via } \\
\text { activation } \\
\text { of the } \\
\text { MAPK/Erk- } \\
1 / 2 \\
\text { pathway - } \\
\text { increases } \\
\text { Bcl-2 } \\
\text { protein } \\
\text { levels }\end{array}$ & Intestinal & Int407 & $\begin{array}{l}\text { (Wikström } \\
\text { et al., } \\
2003)\end{array}$ \\
\hline $\mathrm{LTD}_{4}$ & & & & & $\begin{array}{l}\text { Colorectal } \\
\text { cancer }\end{array}$ & Caco-2 & \\
\hline
\end{tabular}




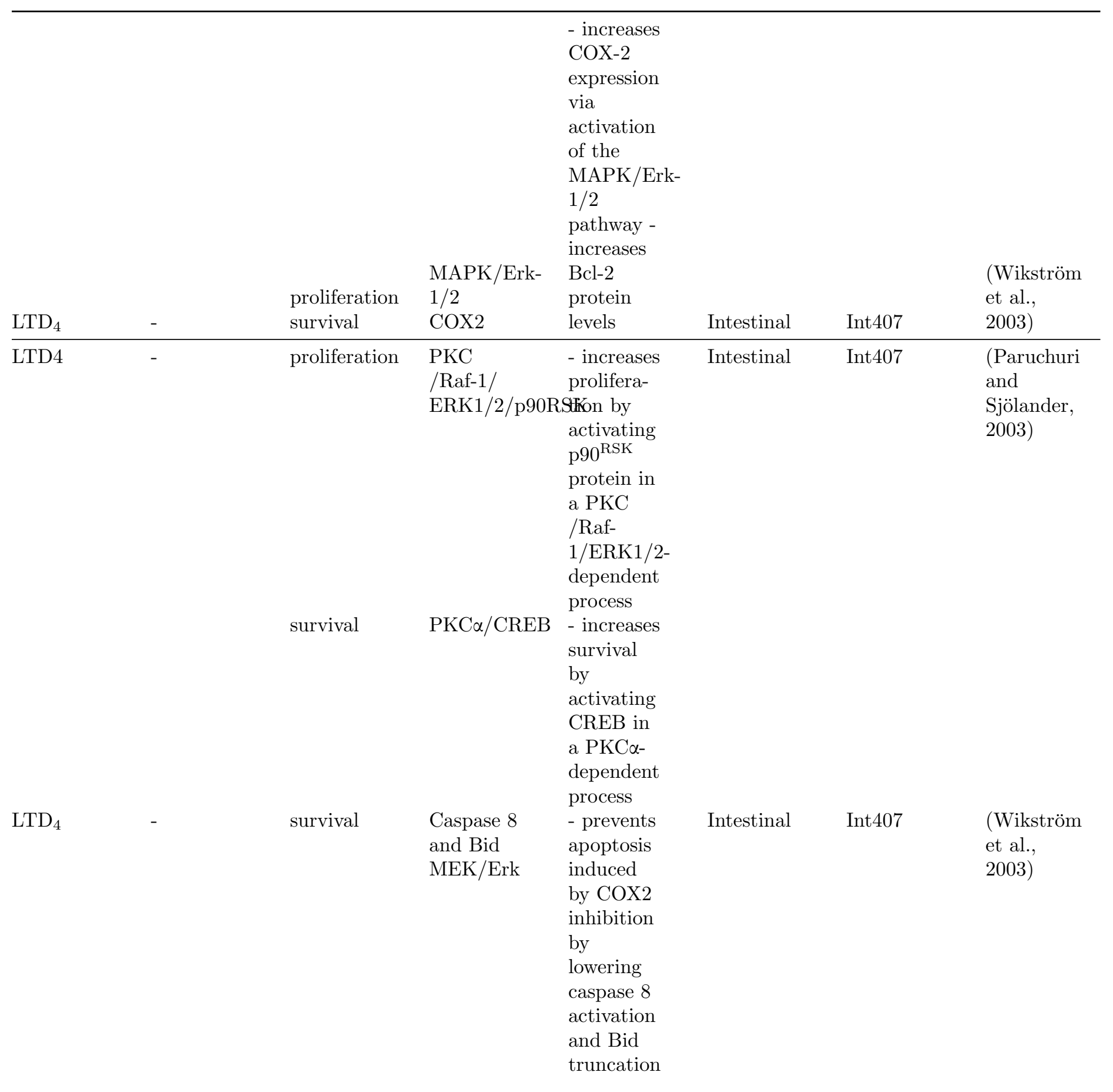




\begin{tabular}{|c|c|c|c|c|c|c|c|}
\hline $\mathrm{LTD}_{4}$ & - & $\begin{array}{l}\text { proliferation } \\
\text { survival }\end{array}$ & $\begin{array}{l}\text { MAPK/Erk- } \\
1 / 2 \\
\text { COX2 }\end{array}$ & $\begin{array}{l}\text { - increases } \\
\text { COX-2 } \\
\text { expression } \\
\text { via } \\
\text { activation } \\
\text { of the } \\
\text { MAPK/Erk- } \\
1 / 2 \\
\text { pathway - } \\
\text { increases } \\
\text { Bcl-2 } \\
\text { protein } \\
\text { levels }\end{array}$ & Intestinal & Int407 & $\begin{array}{l}\text { (Wikström } \\
\text { et al., } \\
2003 \text { ) }\end{array}$ \\
\hline$\overline{\mathrm{LTD}_{4}}$ & - & $\begin{array}{l}\text { proliferation } \\
\text { survival }\end{array}$ & $\begin{array}{l}\mathrm{PI} 3 \mathrm{~K} / \text { Akt/G } \\
3 \beta \\
\mathrm{PKC} / \text { Erk- } \\
1 / 2\end{array}$ & $\begin{array}{l}\text { K-induces } \\
\beta \text {-catenin } \\
\text { transloca- } \\
\text { tion to the } \\
\text { nucleus } \\
\text { and asso- } \\
\text { ciation } \\
\text { with cell } \\
\text { survival } \\
\text { protein } \\
\text { Bcl2 } \\
\text { mediated } \\
\text { by a } \\
\text { PI3K- } \\
\text { dependent } \\
\text { phospho- } \\
\text { rylation of } \\
\text { GSK-3 }\end{array}$ & Intestinal & Int407 & $\begin{array}{l}\text { (Mezhybovska } \\
\text { et al., } \\
2006)\end{array}$ \\
\hline $\mathrm{LTD}_{4}$ & $\mathrm{CysLT}_{1} \mathrm{R}$ & proliferation & - & $\begin{array}{l}\text { - in- } \\
\text { creases cell } \\
\text { proliferation }\end{array}$ & $\begin{array}{l}\text { Colorectal } \\
\text { cancer }\end{array}$ & Caco-2 & $\begin{array}{l}\text { (Magnusson } \\
\text { et al., } \\
2007 \text { ) }\end{array}$ \\
\hline
\end{tabular}




\begin{tabular}{|c|c|c|c|c|c|c|c|}
\hline $\mathrm{LTD}_{4}$ & - & $\begin{array}{l}\text { proliferation } \\
\text { survival }\end{array}$ & $\begin{array}{l}\text { MAPK/Erk- } \\
1 / 2 \\
\text { COX2 }\end{array}$ & $\begin{array}{l}\text { - increases } \\
\text { COX-2 } \\
\text { expression } \\
\text { via } \\
\text { activation } \\
\text { of the } \\
\text { MAPK/Erk- } \\
1 / 2 \\
\text { pathway - } \\
\text { increases } \\
\text { Bcl-2 } \\
\text { protein } \\
\text { levels }\end{array}$ & Intestinal & Int407 & $\begin{array}{l}\text { (Wikström } \\
\text { et al., } \\
2003 \text { ) }\end{array}$ \\
\hline $\mathrm{LTC}_{4}$ & $\mathrm{CysLT}_{2} \mathrm{R}$ & $\begin{array}{l}\text { differentiation } \\
\text { survival }\end{array}$ & $\begin{array}{l}\text { alkaline } \\
\text { phos- } \\
\text { phatase } \\
\text { and } \\
\text { aminopep- } \\
\text { tidase } \\
\text { N }\end{array}$ & $\begin{array}{l}\text { - induces } \\
\text { cell differ- } \\
\text { enciation } \\
\text { markers: } \\
\text { increases } \\
\text { alkaline } \\
\text { phos- } \\
\text { phatase } \\
\text { activity } \\
\text { and } \\
\text { enhances } \\
\text { NaBT- } \\
\text { induced } \\
\text { increase of } \\
\text { aminopep- } \\
\text { tidase N } \\
\text { activity - } \\
\text { increases } \\
\text { caspase } 3 \\
\text { activity } \\
\text { and } \\
\text { enhances } \\
\text { sodium } \\
\text { butyrate- } \\
\text { induced } \\
\text { apoptosis }\end{array}$ & $\begin{array}{l}\text { Colorectal } \\
\text { cancer }\end{array}$ & Caco-2 & $\begin{array}{l}\text { (Magnusson } \\
\text { et al., } \\
2007 \text { ) }\end{array}$ \\
\hline $\mathrm{LTD}_{4}$ & $\mathrm{CysLT}_{1} \mathrm{R}$ & $\begin{array}{l}\text { adhesion } \\
\text { proliferation }\end{array}$ & $\begin{array}{l}\mathrm{p} 44 / 42 \\
\text { ERK/MAPK } \\
\text { Pyk } 2\end{array}$ & $\begin{array}{l}\text { - upregu- } \\
\text { lates } \alpha 4 \beta 1 \\
\text { and } \alpha 5 \beta 1 \\
\text { integrin- } \\
\text { dependent } \\
\text { adhesion - } \\
\text { enhances } \\
\text { cytokine- } \\
\text { induced } \\
\text { proliferation }\end{array}$ & Stem cells & $\begin{array}{l}\text { CD34+ } \\
\text { hemato- } \\
\text { poietic } \\
\text { progenitor } \\
\text { cells }\end{array}$ & $\begin{array}{l}\text { (Boehmler } \\
\text { et al., } \\
2009)\end{array}$ \\
\hline
\end{tabular}




\begin{tabular}{|c|c|c|c|c|c|c|c|}
\hline & - & $\begin{array}{l}\text { proliferation } \\
\text { survival }\end{array}$ & $\begin{array}{l}\text { MAPK/Erk- } \\
1 / 2 \\
\text { COX2 }\end{array}$ & $\begin{array}{l}\text { - increases } \\
\text { COX-2 } \\
\text { expression } \\
\text { via } \\
\text { activation } \\
\text { of the } \\
\text { MAPK/Erk- } \\
1 / 2 \\
\text { pathway - } \\
\text { increases } \\
\text { Bcl-2 } \\
\text { protein } \\
\text { levels }\end{array}$ & Intestinal & Int407 & $\begin{array}{l}\text { (Wikström } \\
\text { et al., } \\
2003 \text { ) }\end{array}$ \\
\hline $\mathrm{LTD}_{4}$ & $\mathrm{CysLT}_{1} \mathrm{R}$ & $\begin{array}{l}\text { migration } \\
\text { metastasis }\end{array}$ & $\mathrm{EGF} / \mathrm{Rac} 1 / \mathrm{T}$ & $\begin{array}{l}\text { am1 } \\
\text { LTC4/LTD4 } \\
\text { regulates } \\
\text { the second } \\
\text { EGF- } \\
\text { induced } \\
\text { wave of } \\
\text { Rac1 } \\
\text { activation } \\
\text { by } \\
\text { increasing } \\
\text { Tiam1 } \\
\text { expression }\end{array}$ & $\begin{array}{l}\text { Epidermal } \\
\text { carcinoma }\end{array}$ & A 431 & $\begin{array}{l}\text { (Magi et } \\
\text { al., 2014) }\end{array}$ \\
\hline
\end{tabular}




\begin{tabular}{|c|c|c|c|c|c|c|c|}
\hline $\mathrm{LTD}_{4}$ & - & $\begin{array}{l}\text { proliferation } \\
\text { survival }\end{array}$ & $\begin{array}{l}\text { MAPK/Erk- } \\
1 / 2 \\
\text { COX2 }\end{array}$ & $\begin{array}{l}\text { - increases } \\
\text { COX-2 } \\
\text { expression } \\
\text { via } \\
\text { activation } \\
\text { of the } \\
\text { MAPK/Erk- } \\
1 / 2 \\
\text { pathway - } \\
\text { increases } \\
\text { Bcl-2 } \\
\text { protein } \\
\text { levels }\end{array}$ & Intestinal & Int407 & $\begin{array}{l}\text { (Wikström } \\
\text { et al., } \\
2003 \text { ) }\end{array}$ \\
\hline $\mathrm{LTD}_{4}$ & $\mathrm{CysLT}_{1} \mathrm{R}$ & $\begin{array}{l}\text { Proliferation } \\
\text { migration }\end{array}$ & 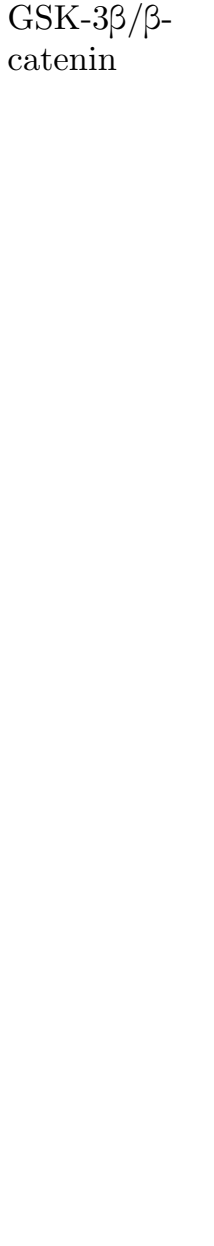 & $\begin{array}{l}\text { - increases } \\
\beta \text {-catenin } \\
\text { expression - } \\
\text { induces } \\
\beta \text {-catenin } \\
\text { nuclear } \\
\text { transloca- } \\
\text { tion and the } \\
\text { subsequent } \\
\text { transcription } \\
\text { of MYC and } \\
\text { CCND1- } \\
\text { induced } \\
\text { EMT : } \\
\text { reduces } \\
\text { expression of } \\
\text { E-cadherin } \\
\text { and } \\
\beta \text {-catenin at } \\
\text { the plasma } \\
\text { membrane- } \\
\text { increases } \\
\text { migration } \\
\text { and } \\
\text { proliferation- } \\
\text { inhibits } \\
\text { GSK-3 } \beta \\
\text { activity } \\
\text { (increases its } \\
\text { phosphorylatic }\end{array}$ & $\begin{array}{l}\text { Colorectal } \\
\text { cancer } \\
\text { n) }\end{array}$ & НСТ-116 & $\begin{array}{l}\text { (Salim et al., } \\
2014 \text { ) }\end{array}$ \\
\hline
\end{tabular}




\begin{tabular}{|c|c|c|c|c|c|c|c|}
\hline $\mathrm{LTD}_{4}$ & - & $\begin{array}{l}\text { proliferation } \\
\text { survival }\end{array}$ & $\begin{array}{l}\text { MAPK/Erk- } \\
1 / 2 \\
\text { COX2 }\end{array}$ & $\begin{array}{l}\text { - increases } \\
\text { COX-2 } \\
\text { expression } \\
\text { via } \\
\text { activation } \\
\text { of the } \\
\text { MAPK/Erk- } \\
1 / 2 \\
\text { pathway - } \\
\text { increases } \\
\text { Bcl-2 } \\
\text { protein } \\
\text { levels }\end{array}$ & Intestinal & Int407 & $\begin{array}{l}\text { (Wikström } \\
\text { et al., } \\
2003 \text { ) }\end{array}$ \\
\hline $\mathrm{LTD}_{4}$ & $\mathrm{CysLT}_{1} \mathrm{R}$ & $\begin{array}{l}\text { stemness } \\
\text { survival } \\
\text { proliferation }\end{array}$ & $\begin{array}{l}\text { Bcl-2 } \\
\text { Bcl-3 } \\
\text { COX-2 }\end{array}$ & $\begin{array}{l}\text { - increases } \\
\text { ALDH+ } \\
\text { CICs } \\
\text { population } \\
\text { - increases } \\
\text { gene } \\
\text { expression } \\
\text { of Bcl-2 } \\
\text { and Bcl-3 } \\
\text { - increases } \\
\text { expression } \\
\text { of COX-2 } \\
\text { - increases } \\
\text { colony } \\
\text { formation } \\
\text { capacity } \\
\text {-increases } \\
\text { tumor } \\
\text { growth in } \\
\text { a } \\
\text { xenograft } \\
\text { model of } \\
\text { colon } \\
\text { cancer - } \\
\text { increases } \\
\text { resistance } \\
\text { to } \\
\text { radiation } \\
\text { and 5-FU }\end{array}$ & $\begin{array}{l}\text { Colorectal } \\
\text { cancer }\end{array}$ & $\begin{array}{l}\text { НCТ-116, } \\
\text { Сaco-2 }\end{array}$ & $\begin{array}{l}\text { (Bellamkonda } \\
\text { et al., } \\
2015 \text { ) }\end{array}$ \\
\hline
\end{tabular}




\begin{tabular}{|c|c|c|c|c|c|c|c|}
\hline $\mathrm{LTD}_{4}$ & - & $\begin{array}{l}\text { proliferation } \\
\text { survival }\end{array}$ & $\begin{array}{l}\text { MAPK/Erk- } \\
1 / 2 \\
\text { COX2 }\end{array}$ & $\begin{array}{l}\text { - increases } \\
\text { COX-2 } \\
\text { expression } \\
\text { via } \\
\text { activation } \\
\text { of the } \\
\text { MAPK/Erk- } \\
1 / 2 \\
\text { pathway - } \\
\text { increases } \\
\text { Bcl-2 } \\
\text { protein } \\
\text { levels }\end{array}$ & Intestinal & Int407 & $\begin{array}{l}\text { (Wikström } \\
\text { et al., } \\
2003 \text { ) }\end{array}$ \\
\hline $\mathrm{LTD}_{4}$ & $\mathrm{CysLT}_{1} \mathrm{R}$ & $\begin{array}{l}\text { invasion } \\
\text { migration }\end{array}$ & $\begin{array}{l}\beta \text {-catenin } \\
\text { MMP-9 }\end{array}$ & $\begin{array}{l}\text { - increases } \\
\text { expression } \\
\text { of MMP-9 } \\
\text { - induces } \\
\text { EMT } \\
\text { markers } \\
\text { (stabiliza- } \\
\text { tion/nuclear } \\
\text { transloca- } \\
\text { tion of } \\
\beta \text {-catenin) } \\
\text { - increases } \\
\text { invasion }\end{array}$ & $\begin{array}{l}\text { Colorectal } \\
\text { cancer }\end{array}$ & SW480 & $\begin{array}{l}\text { (Vinnakota } \\
\text { et al., } \\
2017 \text { ) }\end{array}$ \\
\hline $\mathrm{LTC}_{4}$ & $\mathrm{CysLT}_{2} \mathrm{R}$ & Differentiation & $\begin{array}{l}\text { JNK/AP- } \\
1\end{array}$ & $\begin{array}{l}\text { - upregu- } \\
\text { lates } \\
\text { tumor } \\
\text { suppressor } \\
\text { 15-PGDH } \\
\text { via } \\
\text { JNK/AP- } \\
1 \\
\text { phospho- } \\
\text { rylation - } \\
\text { increases } \\
\text { expression } \\
\text { of differ- } \\
\text { entiation } \\
\text { markers } \\
\text { sucrase- } \\
\text { isomaltase } \\
\text { and } \\
\text { mucin-2 - } \\
\text { downregu- } \\
\text { lates } \\
\text { COX-2 } \\
\text { expression }\end{array}$ & $\begin{array}{l}\text { Colorectal } \\
\text { cancer }\end{array}$ & HT-29 & $\begin{array}{l}\text { (Mehdawi } \\
\text { et al., } \\
2017 \text { ) }\end{array}$ \\
\hline
\end{tabular}




\begin{tabular}{|c|c|c|c|c|c|c|c|}
\hline $\mathrm{LTD}_{4}$ & - & $\begin{array}{l}\text { proliferation } \\
\text { survival }\end{array}$ & $\begin{array}{l}\text { MAPK/Erk- } \\
1 / 2 \\
\text { COX2 }\end{array}$ & $\begin{array}{l}\text { - increases } \\
\text { COX-2 } \\
\text { expression } \\
\text { via } \\
\text { activation } \\
\text { of the } \\
\text { MAPK/Erk- } \\
1 / 2 \\
\text { pathway - } \\
\text { increases } \\
\text { Bcl-2 } \\
\text { protein } \\
\text { levels }\end{array}$ & Intestinal & Int407 & $\begin{array}{l}\text { (Wikström } \\
\text { et al., } \\
2003 \text { ) }\end{array}$ \\
\hline $\mathrm{LTC}_{4}$ & $\mathrm{CysLT}_{2} \mathrm{R}$ & $\begin{array}{l}\text { survival } \\
\text { migration }\end{array}$ & $\begin{array}{l}\beta \text {-catenin } \\
\text { Bcl-2 } \\
\text { Caspase } 3 \\
\text { MMP-2/9 } \\
\text { VEGFR }\end{array}$ & $\begin{array}{l}\text { - phospho- } \\
\text { rylates } \\
\beta \text {-catenin - } \\
\text { downregu- } \\
\text { lates Bcl-2 } \\
\text { and } \\
\text { activates } \\
\text { Caspase-3 } \\
\text { - induces } \\
\text { 15-PGDH } \\
\text { in a TNF } \alpha \\
\text { dependent } \\
\text { manner - } \\
\text { decreases } \\
\text { MMP-2 } \\
\text { and -9, } \\
\text { and } \\
\text { VEGFR-1 } \\
\text { levels }\end{array}$ & $\begin{array}{l}\text { Colorectal } \\
\text { cancer }\end{array}$ & $\begin{array}{l}\text { HT-29 } \\
\text { Caco-2 }\end{array}$ & $\begin{array}{l}\text { (Satapathy } \\
\text { and } \\
\text { Sjolander, } \\
2018)\end{array}$ \\
\hline $\mathrm{LTD}_{4}$ & CysLT1R & metabolism & - & $\begin{array}{l}\text { - upregu- } \\
\text { lates } \\
\text { COX-2 } \\
\text { expression- } \\
\text { increases } \\
\text { CysLT1R } \\
\text { and } \\
\text { CysLT2R } \\
\text { expression }\end{array}$ & Intestinal & Int407 & $\begin{array}{l}\text { (Yudina et } \\
\text { al., 2008) }\end{array}$ \\
\hline
\end{tabular}




\begin{tabular}{|c|c|c|c|c|c|c|c|}
\hline $\mathrm{LTD}_{4}$ & - & $\begin{array}{l}\text { proliferation } \\
\text { survival }\end{array}$ & $\begin{array}{l}\text { MAPK/Erk- } \\
1 / 2 \\
\text { COX2 } \\
\end{array}$ & $\begin{array}{l}\text { - increases } \\
\text { COX-2 } \\
\text { expression } \\
\text { via } \\
\text { activation } \\
\text { of the } \\
\text { MAPK/Erk- } \\
1 / 2 \\
\text { pathway - } \\
\text { increases } \\
\text { Bcl-2 } \\
\text { protein } \\
\text { levels } \\
\end{array}$ & Intestinal & Int407 & $\begin{array}{l}\text { (Wikström } \\
\text { et al., } \\
2003 \text { ) }\end{array}$ \\
\hline $\mathrm{LTD}_{4}$ & $\mathrm{CysLT}_{1} \mathrm{R}$ & Inflammation & EGR-1 & $\begin{array}{l}\text { - increases } \\
5 \text {-LOX } \\
\text { and } \\
\text { LTC4S } \\
\text { expression } \\
\text { - decreases } \\
\text { CysLT1R } \\
\text { expression } \\
\text { and } \\
\text { increases } \\
\text { CysLT2R } \\
\text { expression } \\
\text { - increases } \\
\text { TNF- } \alpha \text {, } \\
\text { IL-6, IL-8, } \\
\text { CCL-3 } \\
\text { and CCL4 } \\
\text { via } \\
\text { induction } \\
\text { of tran- } \\
\text { scription } \\
\text { factor } \\
\text { EGR-1 } \\
\text { expression }\end{array}$ & $\begin{array}{l}\text { Colorectal } \\
\text { cancer }\end{array}$ & $\begin{array}{l}\text { Caco-2, } \\
\text { HT-29, } \\
\text { SW-480, } \\
\text { HCT-116 }\end{array}$ & $\begin{array}{l}\text { (Schain et } \\
\text { al., 2008), } \\
\text { (Han et } \\
\text { al., 2015) }\end{array}$ \\
\hline
\end{tabular}




\begin{tabular}{|c|c|c|c|c|c|c|c|}
\hline $\mathrm{LTD}_{4}$ & - & $\begin{array}{l}\text { proliferation } \\
\text { survival }\end{array}$ & $\begin{array}{l}\text { MAPK/Erk- } \\
1 / 2 \\
\text { COX2 }\end{array}$ & $\begin{array}{l}\text { - increases } \\
\text { COX-2 } \\
\text { expression } \\
\text { via } \\
\text { activation } \\
\text { of the } \\
\text { MAPK/Erk- } \\
1 / 2 \\
\text { pathway - } \\
\text { increases } \\
\text { Bcl-2 } \\
\text { protein } \\
\text { levels }\end{array}$ & Intestinal & Int407 & $\begin{array}{l}\text { (Wikström } \\
\text { et al., } \\
2003 \text { ) }\end{array}$ \\
\hline $\mathrm{LTD}_{4}$ & $\begin{array}{l}\text { not } \\
\text { specified }\end{array}$ & metabolism & $\beta$-catenin & $\begin{array}{l}\text { - increases } \\
\text { NADPH, } \\
\text { ATP/ADP } \\
\text { ratio and } \\
\text { transcrip- } \\
\text { tion of } \\
\text { mtDNA } \\
\text { genes via } \\
\beta \text {-catenin } \\
\text { accumula- } \\
\text { tion - } \\
\text { increases } \\
\text { ROS levels } \\
\text { and subse- } \\
\text { quent } \\
\text { NF- } \varkappa B\end{array}$ & Intestinal & Int407 & $\begin{array}{l}\text { (Mezhybovska } \\
\text { et al., } \\
2009 \text { ) }\end{array}$ \\
\hline
\end{tabular}

\section{FIGURE LEGENDS}

Figure 1. Leukotrienes, structures and biosynthesis. A. Key enzymes and metabolites of the leukotriene cascade AA is converted by 5-LOX in conjunction with FLAP into LTA 4 through 5-HPETE. The leukotrienes are divided into two class, $\mathrm{LTA}_{4} \mathrm{H}$ metabolites such as $\mathrm{LTB}_{4}$ and LTC4S metabolites, cysteinyl leukotrienes. B. Biosynthesispathway of cysteinyl leukotrienes. Upon cellular stimulation, intracellular $\mathrm{Ca}^{2+}$ is increased leading to translocation of $\mathrm{cPLA}_{2} \alpha$ and 5-LOX to the nuclear membrane. $\mathrm{cPLA}_{2} \alpha$ releases membrane phospholipids to produce free AA which is presented to 5-LOX by FLAP and further converted to $\mathrm{LTA}_{4}$. LTA 4 is conjugated to reduced glutathione by LTC4S to form $\mathrm{LTC}_{4}$, which is exported by MRP 1 and 4 . In the extracellular space, $\mathrm{LTC}_{4}$ is converted to $\mathrm{LTD}_{4}$ by GGT and $\mathrm{LTD}_{4}$ to $\mathrm{LTE}_{4}$ by DPEP. Cysteinyl leukotrienes $\mathrm{LTC}_{4}$ and $\mathrm{LTD}_{4}$ can bind to two major receptors $\mathrm{CysLT}_{1} \mathrm{R}$ and $\mathrm{CysLT}_{2} \mathrm{R}$ whereas GPR99, or $\mathrm{CysLT}_{3} \mathrm{R}$, is a receptor with high affinity to $\mathrm{LTE}_{4}$. The thickness of the arrows represents the receptor/ligand binding affinity. C. Regulation of the expression of the enzymes of the cysteinyl leukotriene pathway. Various cytokines and molecules have been shown to upregulate (in green) or downregulate (in red) the expression of 5-LOX, LTC4S or GGT. Abbreviations: 5-HPETE, 5-hydroperoxyeicosatetraenoic acid; 5-LOX, 5-lipoxygenase; AA, arachidonic acid; cPLA2 $\alpha$, cytosolic phospholipase A2; DPEP, dipeptidase; FLAP, 5-lipoxygenase-activating protein; GGT, $\gamma$-glutamyl transpeptidases; MRP, multidrug resistance-associated protein.

Figure 2. Role of cysteinyl leukotrienes in carcinogenesis. 
A

Figure 1

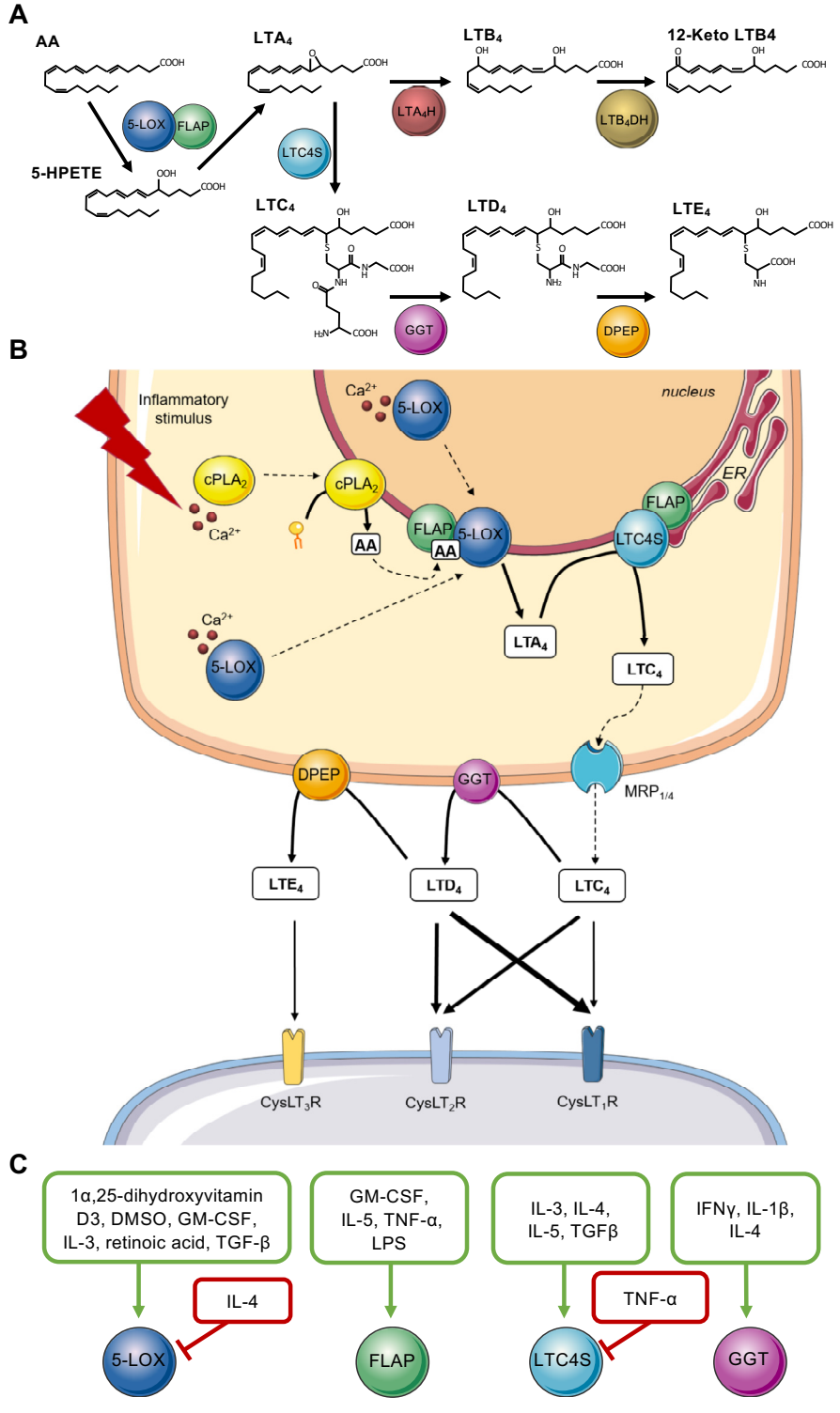


Figure 2

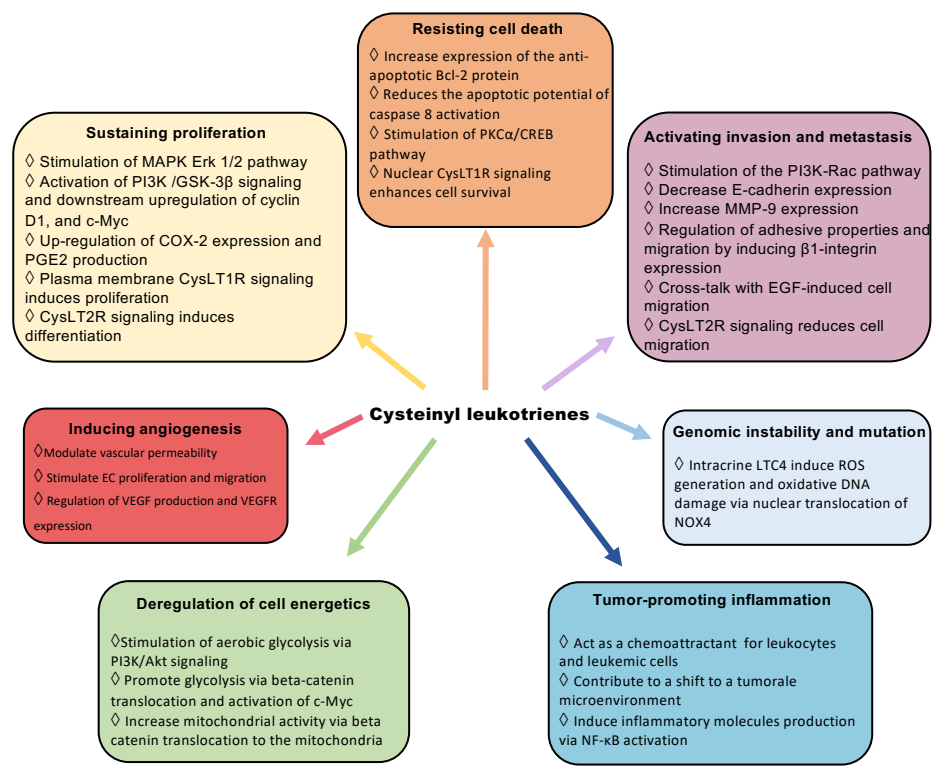

